\title{
B cells biology in systemic lupus erythematosus-from bench to bedside
}

\author{
ZHAO LiDan, YE YanXia \& ZHANG Xuan* \\ Department of Rheumatology \& Clinical Immunology, Peking Union Medical College Hospital, Chinese Academy of Medical Sciences and \\ Peking Union Medical College, Beijing 100730, China
}

Received August 12, 2015; accepted October 9, 2015

\begin{abstract}
Systemic lupus erythematosus (SLE) is a debilitating autoimmune disease that can involve multi-organs. B cells play a central role in the immunopathogenesis via antibody-dependent and antibody-independent ways. Excessive autoantibodies production, hyperresponsiveness and prolonged survival of autoreactive B cells are characteristics of SLE. In this article, mechanisms of self-tolerance loss of B cells and promising B cell-targeting therapies in lupus are reviewed and discussed.
\end{abstract}

systemic lupus erythematosus, B cell, pathogenesis, target therapy

Citation: Zhao LD, Ye YX, Zhang X. B Cells biology in Systemic Lupus Erythematosus-from bench to bedside. Sci China Life Sci, 2015, 58: 1111-1125, doi: 10.1007/s11427-015-4953-X

Systemic lupus erythematosus (SLE), the paradigm of autoimmune disease with the underlying mechanisms involving multiple immunological abnormalities, is a severely debilitating disease with multi-organ involvement and diverse autoantibodies spectrum [1]. Among the multiple elements in the pathogenesis, B cells play a central role in SLE through antibody dependent and independent manners [2]. Presence of pathogenic autoantibodies is not only the hallmark of SLE and the clue for diagnosis, but also associated with characteristic pathological injury and specific clinical manifestations [3-5]. In addition, the pathogenic role of B cells is also attributed to its antibody independent functions, including but not limited to antigen presentation, T cell crosstalk, dendritic cells (DCs) recruitment, pro-inflammatory cytokine secretion. Why and how auto-reactive B cells in lupus lose self-tolerance, escape from central and peripheral checkpoints, become over-activated and spontaneously produce autoantibodies, are always the focus of clinical and basic research. Therefore, it is important to summarize our current knowledge

*Corresponding author (email: zxpumch2003@ sina.com) about the underlying mechanisms of self-tolerance breakdown and pathogenic functioning pathways of B cells in SLE. So we review here about B cell biology in SLE, including its differentiation and selection, functioning and signaling, surviving and apoptosis, and the resulting potential therapeutic targets both in mice and human lupus.

\section{Role of $B$ cells in the pathogenesis of SLE- antibody dependent and independent mecha- nisms}

Naïve B cells undergo the process of heavy chain $\mathrm{V}$ region gene rearrangement, isotype switching, somatic hypermutation and affinity-based selection within germinal center (GC), then leave GC and develop into memory B cells , or alternatively, short lived or long lived plasma cells that are capable of producing antibodies including pathogenic autoantibodies [6], which is crucial for triggering and perpetuating disease in SLE. Various abnormality of the development, status and functions of B cells have been reported, 
including activation thresholds lowering, prolonged survival and inhibition of apoptotic processing [7,8].

Although the spectrum of lupus manifestations is diverse, indicating the heterogeneous nature of SLE, circulating autoantibodies is ubiquitous and is related to target organ injury and disease activity with diagnostic value [2,3]. For example, anti-Smith antibody is highly specific and pathognomonic for SLE [9,10]. Higher titers of anti-double strain DNA antibody (anti-dsDNA) correlates with lupus nephritis (LN) and disease activity [11,12]. The presence of anti-ribosomal $\mathrm{P}$ antibody predicts an increased risk of neuropsychiatric event $[13,14]$. Patients with antibody against Sjogren syndrome antigen A (anti-SSA or anti-Ro) are predisposed to photosensitivity, rash and haematological disorders $[15,16]$. Pregnant women with anti-SSA may give birth to babies with congenital heart block [17].

But the immunological role of B cell is not limited to the precursor of immunoglobulin (Ig) secreting cell, namely plasma cell. Mice with normal numbers of B cells but lacking of circulating antibodies (mIgM MRL/MP-Fas ${ }^{\text {lpr }}$ mice that expressmembrane-bound IgM but lack exons needed for secretion) still exhibit autoimmunity and accelerated mortality [18], whereas B cell-deficient MRL/lpr mice are resistant to development of lupus-like disease [19,20]. These data collectively indicate that B cells also play an autoantibody-independent role in SLE pathogenesis. Actually, B cells exert multipotent immunological functions such as presenting antigen, co-stimulating $\mathrm{T}$ cells, inducing immunogenic DCs, as well as producing cytokines and chemokines to promote inflammation, affect immune regulation and lymphogenesis (Figure 1) [2,21,22].

\subsection{Autoreactive $B$ cells and $B_{R E G}$ in SLE}

SLE B cells can be divided into pathogenic autoreactive B cells that are involved in autoimmune response, protective $\mathrm{B}$ cells that are involved in immune defense against pathogenic microorganisms and regulatory $B$ cells $\left(B_{R E G}\right)$ that help to keep self tolerance and immune homeostasis [23]. Abnormal proportional composition of $\mathrm{B}$ cell subgroups and accumulation of autoreactive B cells in murine and human SLE have been reported [24,25]. Autoreactive B cells exist in all human but with higher frequency in patients with SLE [26]. Moreover, defects of $B_{\text {REG }}$ in numbers and/or functions may also contribute to inordinate immunological state in SLE [27,28]. Before entering peripheral circulation, B cells have to be checked for their autoreactivity, those with high affinity with autoantigens are deleted or anergized. Two major mechanisms in central and peripheral checkpoints are clonal deletion and receptor editing [29]. Additional censoring mechanisms may exist, as studies showed that $50 \%-75 \%$ immature B cells newly emerging into periphery can be autoreactive [30] and up to $20 \%$ of peripheral mature naïve $\mathrm{B}$ cells in normal individuals are reactive with self nuclear antigens $[7,26]$.

\subsubsection{Autoreactive B cell}

Although pathogenic, lymphocytopenia other than lymphocytosis of B cells is often found in active SLE [6]. Disturbance of B cell homoeostasis with an abnormal shift of pre-immature B cell pool towards more immature subgroups independent of disease activity in peripheral blood has been noted, including expanded pre-naïve B cells and transitional $B$ cells [31,32]. Marked reduction of naïve peripheral $\mathrm{CD} 19^{+} \mathrm{CD} 27^{-} \mathrm{B}$ cells mainly account for $\mathrm{B}$ lymphocytopenia [6]. Whereas increased frequency of CD2 $7^{\text {high }}$ plasmablasts seems to correlate with active disease $[6,25,33]$ and abates significantly after immunosuppressive therapy. Ig heavy chain variable $\left(\mathrm{V}_{\mathrm{H}}\right)$ gene analysis has demonstrated extraordinary highly mutated and clonally

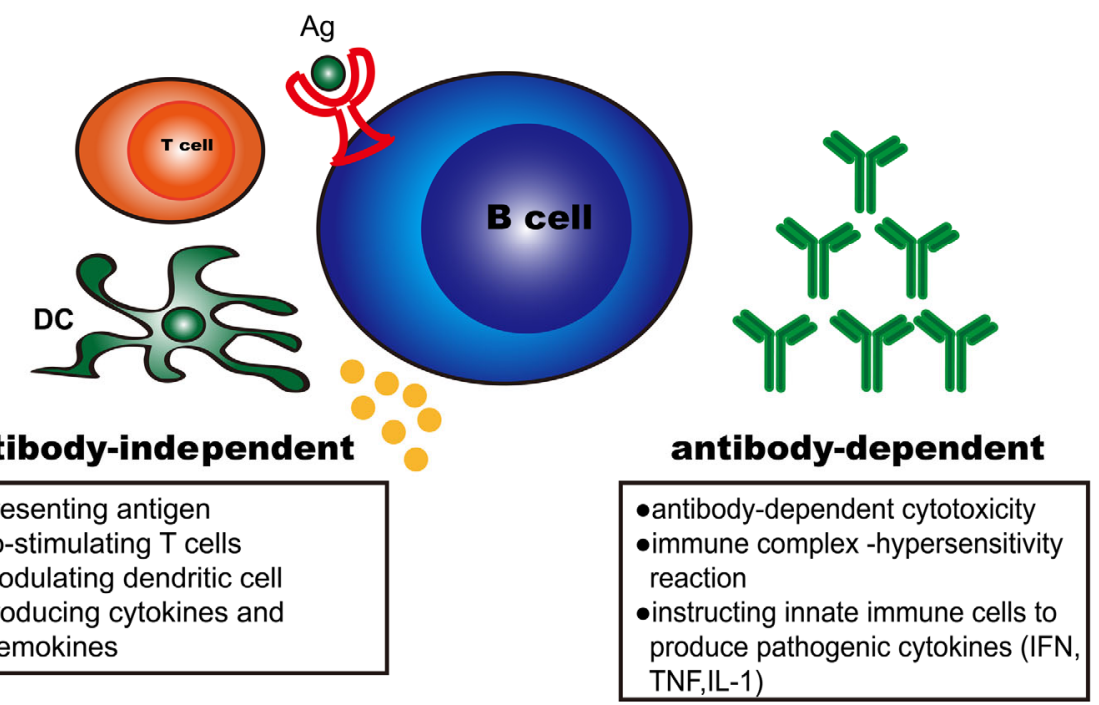

Figure 1 Antibody-dependent and -independent role of B cells in the pathogenesis of systemic lupus erythematosus. Ag, antigen; DC, dendritic cell; IFN, interferon; TNF, tumor necrosis factor. 
related $\mathrm{V}_{\mathrm{H}}$ gene rearrangements within $\mathrm{CD} 27^{\text {high }}$ plasmablasts, indicating autoreactive nature of this population. In addition, $\mathrm{CD} 27^{+} \mathrm{IgD}^{-}$antigen-experienced post-switched memory B cells are also expanded in SLE patients. These cells express less inhibitory $\mathrm{IgG}$ Fc receptor-Fc $\gamma \mathrm{RIIB}$, are resistant to immunosuppressive drugs [34], and are easily and rapidly activated independent of antigen [35].

\subsubsection{Abnormality of $B_{R E G}$}

$\mathrm{B}_{\mathrm{REG}}$ are capable of secreting IL-10 and controlling $\mathrm{T}$ cell proliferation [36]. In mice, $\mathrm{CD} 19^{\text {high }} \mathrm{CD} 1 \mathrm{~d}^{\text {high }} \mathrm{CD}^{+} \mathrm{B}$ subset capable of producing IL-10 is deemed to be $\mathrm{B}_{\mathrm{REG}}$ [37]. And in human, IL-10 secreting $B$ cells with the phenotype of $\mathrm{CD} 19^{+} \mathrm{CD} 24^{\text {high }} \mathrm{CD} 38^{\text {high }}$ are thought to be $\mathrm{B}_{\mathrm{REG}}[27,38]$. $\mathrm{B}_{\mathrm{REG}}$ could protect mice from development of lupus disease [39]. It has been also reported that $B_{\text {REG }}$ in SLE patients produces less IL-10 and has compromised suppressive capacity $[27,28]$. The role of $B_{\text {REG }}$ and IL-10 in SLE is controversial and paradoxical. For example, Yin et al. [40] reported that IL-10 deficient mice developed more severe lupus, whereas Llorente et al. [41] reported that blockade of IL-10 with antibodies reduced disease activity, indicating a double-side role of IL-10 in SLE.

\subsection{Self-tolerance breakdown of SLE B cells}

Multiple mechanisms to eliminate autoreactive B cells exist to keep self tolerance and ensure normal humoral response to exogenous pathogens. Self-tolerance breakdown contributes to differentiation and expansion, activation and survival of autoreactive B cells in SLE. But the precise mechanisms remain to be illuminated.

\subsubsection{Gene associations with the loss of self-tolerance in B cells}

Combination of gene loci constitutes the genetic background of lupus predisposition. Many of these loci are associated with abnormalities of B cells $[42,43]$. Genome-wide association studies identify a series of candidate lupus-susceptible genes including those encoding BANK (B-lymphocyte scaffold protein with ankyrin repeats), BLK (B-lymphoid tyrosine kinase), PTPN22 (protein tyrosine phosphatase non-receptor type 22), Blimp-1, Lyn, Fc $\gamma$ IIRB, CD22 (cluster of differentiation 22), CD40L (cluster of differentiation 40 ligand) and AID (the activation-induced deaminase). These genes are associated with altered BCR (B cell receptor) signaling, B cell hyper-responsiveness and stimulative differentiation into plasma cells [44-46].

In murine lupus, Sle1, Sle2, Sle3, Yaa are found to be susceptibility genes and might impair BCR signaling and impede antigen-driven negative selection, thus contribute to breakdown of self-tolerance in B cells $[47,48]$.

\subsubsection{Surface molecules on B cells}

CD40 in lipid raft is decreased on activated B cells from SLE [49], but functionally active CD154 (CD40L) expression on SLE B cells is increased [50,51]. CD154 transgenic mice have increased number and enhanced survival of $B$ cells [52]. Spontaneous proliferation and Ig secretion of peripheral B cells from active lupus patients could be inhibited by blockade of CD154-CD40 interaction [50]. Ligation of CD40 with CD154 provides an important co-stimulation signal and plays an essential role in GC reaction. Studies show that CD40-CD154 interaction could not only induce T cell priming, promote Th2 type cytokines production and enhance $\mathrm{T}$ cell medicated immune effects, but also reciprocally function to promote $\mathrm{B}$ cell proliferation, isotypeswitching, activation and antibody production [50,53-55].

CD5 expression on lupus B cells membrane is characteristically reduced [56]. $\mathrm{CD}^{+} \mathrm{B}$ cells are capable of producing IL-10 and possess regulatory potency [37]. Engagement of BCR and production of IL-6 down-regulate membrane CD5 expression through abnormally enhanced demethylation which can influence the balance of the transcripts of two CD5 isoforms (membrane CD5 and cytoplasmic CD5). As a negative regulator of $\mathrm{BCR}$ signaling, reduced membrane CD5 leads to activation and expansion of autoreactive B cells in SLE [56].

CD22 is a negative modulator of BCR signaling. Expressing on mature $\mathrm{B}$ cells, CD22 help to raise activation thresholds and regulate homeostasis and survival of $\mathrm{B}$ cells [57,58]. CD22-deficient mice are found to have hyper-responsive B cells, increased titers of serum autoantibodies, heightened calcium flux and increased proliferation of $\mathrm{B}$ cells $[59,60]$. Recently, studies in vitro show that epratuzumab, an anti-CD22 mono-clonal antibody, can reduce $\mathrm{B}$ cell count modestly and decrease the proinflammatory cytokines like tumor necrosis factor- $\alpha$ and IL-6 produced by activated B cells without influencing IL-10 level [61]. What's more, epratuzumab can substantially reduce the expression of multiple functional molecules like CD19, CD44, CD62L, then inhibit the hyperactivity and migration of B cells without depleting them [62,63]. Although epratuzumab could induce internalization of CD22, the functional consequence of modulating BCR signaling and reducing $B$ cells results in negative regulation of immune reaction and applies to the treatment of autoimmune disease.

CD45 recruitment and retention in lipid raft with altered isoform have been observed increasing in lupus B cells [64]. CD45 negatively regulates Src family protein tyrosine kinase [65] and increased CD45 is associated with reduced Lyn expression (negative more than active BCR downstream signaling molecule) in lupus B cells [64]. CD45 also lowers BCR signaling threshold thus contributes to B cells hyperactivity [66].

Fc $\gamma$ RIIB (CD32B) contains an ITIM (immunoreceptor 
tyrosine based inhibition motif) domain and mediates inhibition of PIP3/PI3K (phosphatidylinositol 3,4,5-trisphosphate/Phosphoinositide 3-kinases) signaling by activation of SHIP (the Src Homology 2-containing inositol 5'-phosphatase) and dephosphorylation of CD19 [67,68]. Co-engagement of Fc $\gamma$ RIIB and BCR by circulating immune complex could transmit negative regulatory signals to B cell activation and proliferation. Therefore Fc $\gamma$ RIIB is an inhibitory Ig receptor, capable of down-regulating BCR complex signals. Defective Fc $\gamma$ RIIB in SLE B cells contributes to increased calcium influx [69]. Polymorphisms of FcyRIIB with impaired expression and function has reported in SLE, especially on memory B cells [70]. Mice deficient of Fc $\gamma$ RIIB on B cells are prone to develop SLE-like disease with increased susceptibility to autoimmune glomerulonephritis and autoantibodies production [71,72]. Restoration of proper Fc $\gamma$ RIIB expression prevents the expansion and accumulation of autoantibody-producing plasma cells in lupus-prone mice [73]. Polymorphism of Fc $\gamma$ RIIB is associated with SLE susceptibilities due to the failure of localization in membrane lipid rafts $[74,75]$.

CD80/CD86 are constitutively expressed on B cells, and by interacting with $\mathrm{CD} 28$ on $\mathrm{T}$ cells, they could costimulate $\mathrm{T}$ cell activation. Up-regulation of CTLA4 (Cytotoxic $\mathrm{T}$ lymphocyte-associated antigen-4) on $\mathrm{T}$ cells upon activation can block CD80/CD86 binding to CD28 through competitive mechanism. A recombinant human IgG Fc fragment fusion protein, CTLA4-Ig, functioning like CTLA4, could dampen the crosstalk of $\mathrm{T}$ cell and B cell by binding to CD80/CD86. In murine lupus, CTLA4-Ig could reduce autoantibody levels and inhibit $\mathrm{B}$ cell class switch and ameliorate nephritis [76].

\subsubsection{Intracellular signal transduction in B cells}

Abnormal BCR down-stream signaling as indicated by augmented calcium influx and increased phosphorylation of protein tyrosine residues is observed in SLE patients, and may lead to disordered transcription and gene expression [42,77-79]. This may result in defective self-limitation of cell activation and breakdown of self tolerance. BCR comprises of $\operatorname{Ig} \alpha$ and $\operatorname{Ig} \beta$ heterodimer with intracellular ITAM (immunoreceptor tyrosine based activation motif) domain. After BCR linking with antigen, phosphorylation cascade of multiple downstream signaling molecules is initiated to tune B cell activation [80,81]. Firstly, ITAMs are phosphorylated by Src family kinases such as Lyn and Blk, and then Syk (spleen tyrosine kinase) with SH2 (Src homology 2) domain is recruited and phosphorylated, and it in turn activates multiple downstream signaling pathway such as Btk (Bruton's tyrosine kinase), PI3K, ERK (extracellular-signal regulated kinases), JNK (c-terminal Jun kinases), and PLC $\gamma$ (phospholipase $C \gamma$ 2) [42,82]. These molecules are of critical importance in coordinating B cell growth, differentiation, survival, activation and apoptosis [83]. Altered BCR intracellular signaling affects calcium influx and leads to aberrant cellular activation status.

Among these key molecules, Lyn has dual role in B cell activation [84]. By phosphorylating $\operatorname{Ig} \alpha / \operatorname{Ig} \beta$ ITAM domain of BCR complex and CD19, Lyn exerts positive regulation in BCR intracellular signal transduction. But Lyn is also capable of phosphorylating ITIM domain of inhibitory receptors including FcyRIIB and CD22, to attenuate BCR signal $[85,86]$. Transgenic mice deficient in Lyn developed severe nephritis and produced auto-antibodies reminiscent of SLE [87-89]. Mice with heterozygotic defect of Lyn $\left(\mathrm{Lyn}^{+/-}\right)$also had similar manifestations, indicating the pivotal role of Lyn in negative-regulation of BCR signaling [90]. Lyn deficiency in B cells has been found in two thirds of SLE patients, and is associated with heightened spontaneous proliferation, anti-dsDNA antibody and IL-10 production [91,92]. Studies have also suggested that the reduction of Lyn expression on B cells is disease pathognomonic but not related to disease activity [92]. Mechanism of Lyn down-regulation is not clear although altered ubiquitination modification and post-transcription inhibition by elevated microRNA-30a have been suggested [91,93]. On the other hand, mice with constitutively activated Lyn in B cells ( Lyn $^{\text {up/up }}$ mice) also develop circulating autoantibodies and lethal autoimmune glomerulonephritis [94]. Therefore Lyn seems not an ideal therapeutic target because of its dual role in immune-regulation which makes the net effect of intervention on Lyn hardly predicted.

Our group together with other groups has demonstrated that increased PI3K/Akt activation in SLE patients, both in

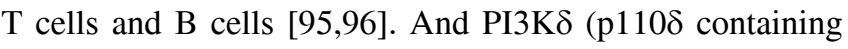
$\mathrm{PI} 3 \mathrm{~K}$ complex) plays an important role in B cell differentiation and function, regulating class switch recombination and AID [97,98]. PI3K is also involved in downstream signal transduction of BCR, BR3 (B lymphocyte stimulator receptor 3), CD40 and TLRs (Toll like receptors) [99,100]. Inactivation of PI3K $\delta$ could lead to significantly decreased autoantibody production and amelioration of autoimmune glomerulonephritis with improved survival in mice model of SLE [101,102].

\subsubsection{B cell tolerance checkpoints}

Peripheral B cell repertoire in SLE is shaped by abnormal selection, exaggerated somatic hypermutation and increased receptor editing. Abnormalities of these checkpoints contribute to defective autoreactive B cells selection [26,103]. During B cell differentiation, central and peripheral tolerance checkpoints serve to eliminate most of the harmful autoreactive B cells (Figure 2) [103]. The stage from immature pre-B to naive $B$ in bone marrow is an important central checkpoint and the mechanisms include receptor 


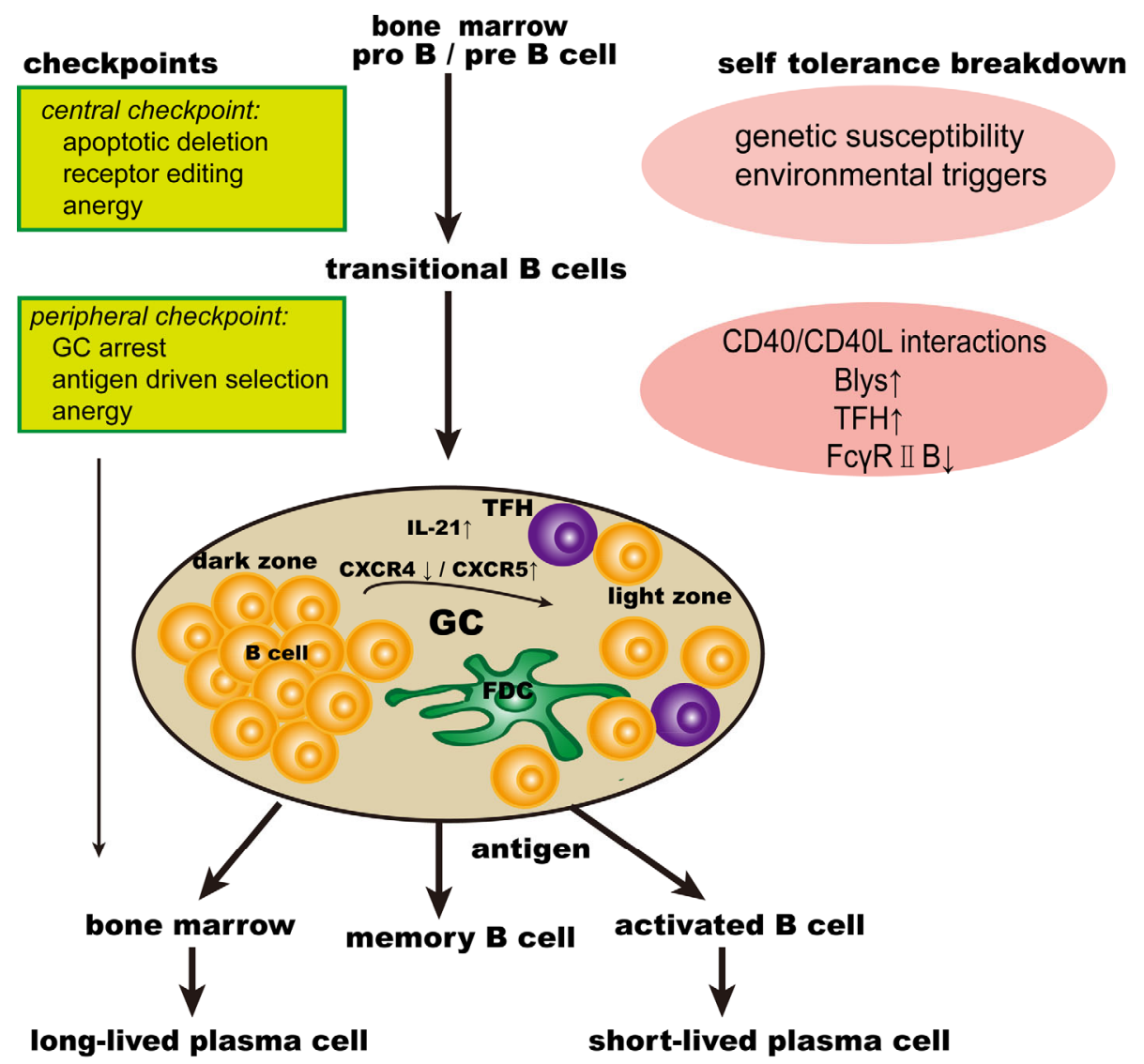

Figure 2 Central and peripheral checkpoints during B cell development. GC, germinal center; TFH, follicular helper T cell; FDC, follicular dendritic cell; Blys, B lymphocyte stimulator; CD40L, CD40 ligand.

editing by $\mathrm{V}(\mathrm{D}) \mathrm{J}$ recombination, clonal deletion by induction of apoptosis and anergy [104,105]. At the stage of pre-BCR, surrogate light chain pairs with Ig heavy chain to form pre-BCR, and multiple mediators may be involved in this checkpoint [106]. Surrogate light chain-deficient mice produce antinuclear antibodies in serum [107]. Decreased RAG-2 transcription may contribute to prolonged survival and decrease apoptosis of pre-B, leading to accumulation of this stage of B cells in lupus mice [108]. Failure of central tolerance checkpoints in human remains largely unknown. Up to $20 \%$ of new emigrant naïve B cells are self-reactive, so peripheral tolerance checkpoint is also important by inhibiting activation and preventing affinity maturation of these self-reactive B cells [30]. In GC, naïve B cells migrate from dark zone where they experience fast proliferation and somatic hypermutation, to light zone where they receive antigen-driven selection under the assistance of follicular helper T cells (TFH) [109]. Self-reactive B cells escaping from GC checkpoints due to migration failure in SLE patients have been reported [110]. Chemokines expressing on $\mathrm{B}$ cells guide the migration and the most important ones are CXCR4 and CXCR5 [111,112]. Abnormal expression of CXCR4 and its ligand in SLE has been reported in several studies and its role in SLE is recognized [113,114]. Considering the important role of TFH in B cells selection, functional status of TFH would contribute to autoreactive B cells escaping into circulation [113,115,116]. Increased numbers of TFH and its association with autoantibody production have been reported in SLE patients and mice [117-119]. IL-21, as one of the signature molecules of TFH, is up-regulated in SLE and leads to expansion of TFH [120-122]. But the precise mechanism that expanded TFH leading to release of autoreacive B cells is not clear. Deficiency of MyD88, IRAK4 (interleukin-1 receptor-associated kinase 4) and UNC-93B contribute to abnormal selection of $\mathrm{B}$ cells in central and peripheral checkpoints $[123,124]$. Defective receptor editing and accumulation of autoreactive $\mathrm{B}$ cells in peripheral blood can be observed in patients with MyD88, IRAK4 or UNC-93B deficiency. These molecules are regulators of TLRs signaling. TLRs signaling especially TLR7, TLR8 and TLR9 are associated with B cell tolerance breakdown $[103,125,126]$. What's more, MyD88, IRAK4 or UNC-93B deficient patients have altered function of regulatory $\mathrm{T}$ cells and DCs, which could also contribute to self tolerance breakdown of B cells [124].

\subsubsection{Cytokines involved in self-tolerance loss of B cells}

Blys (B lymphocyte stimulator, B cell activator of the TNF family): Blys could promote B cell development and sur- 
vival via binding to its receptors: BR3, transmembrane activator-1 and calcium modulator and cyclophillin ligand-interactor (TACI), and B-cell maturation antigen (BCMA) [127-131]. APRIL (a proliferation-inducing ligand) is homology to Blys and shares some biological functions with Blys [132]. TACI and BCMA can bind to both Blys and APRIL [127]. Excessive Blys could rescue autoreactive B cells from deletion and anergy [133,134]. Transgenic mice with over-expression of Blys develop a lupus-like phenotype with excessive numbers of mature $B$ cells and plasma cells, spontaneous GC formation and presence of abundant auto-antibodies [135,136]. In lupusprone mice with elevated circulating Blys levels, blockade of Blys with soluble Blys receptor ameliorates disease progression [137]. Increased Blys levels in serum and occupancy of BR3 on B cells have been demonstrated to be related to disease activity in SLE patients [138-141]. Raised APRIL levels have also been found in SLE patients although they do not correlate with disease activity [142,143]. Excessive Blys and APRIL contribute at least partly to the prolonged survival of auto-reactive B cells [144].

\subsubsection{Other cytokines}

IL-21 is an essential cytokine to co-stimulate B cells differentiating into plasma cells $[122,145]$. IL-21 is mainly produced by TFH in GC and TFH is essential for GC B cells selection [146,147]. Excessive IL-21 in mice can promote autoantibodies production and lupus-like disease [148-150]. Increased IL-21 has also been reported in SLE patients and it correlates with disease activity $[121,151,152]$. Type I IFN (interferon) could promote the differentiation of activated $\mathrm{B}$ cells into plasmablasts and trigger $\mathrm{B}$ cells expansion in conjunction with TLR7 $[153,154]$. IFN $\alpha / \beta$ can also lower activation threshold for autoreactive B cells, enhance B cell resistance to Fas-mediated apoptosis and prolong its survival [155]. Harigai et al. [156] also found IFN $\gamma$ could induce more Blys production and release from lupus monocytes to promote B cells activation. IL-6 is critical for the differentiation of $\mathrm{B}$ cells and promotes the survival of plasmablasts/plasma cells. Excessive IL-6 is reported to correlate closely with lupus disease activity [157]. Anti-IL-6 receptor antibody is shown to be capable of restoring B cell homeostasis by reducing the frequency of abnormally expanded $\mathrm{CD} 27^{\text {high }} \mathrm{CD} 38^{\text {high }} \mathrm{IgD}^{-}$plasmablasts/plasma cells and $\mathrm{CD} 27^{+} \mathrm{IgD}^{-}$post-switched memory $\mathrm{B}$ cells, whereas increasing the frequency of reduced $\mathrm{CD}^{2} 7^{-} \mathrm{IgD}^{+}$naïve $\mathrm{B}$ cells [34].

\section{B-cell targeted therapy in SLE}

Given the pathogenetic role of B cells in SLE, suppressing the production of autoantibodies by depletion of $\mathrm{B}$ cells, inhibition of B cells proliferation or modulation of B cells function is a plausible approach in treating SLE [158]. Of course, due to the complicated mechanisms and heterogeneous nature of SLE, no individual approach would be efficacious for all patients. So far the main approach of B cell targeted therapy can be divided into B cell depletion, B cell inactivation and B cell survival blockade. The molecular target and related biologics are summarized in Figure 3.

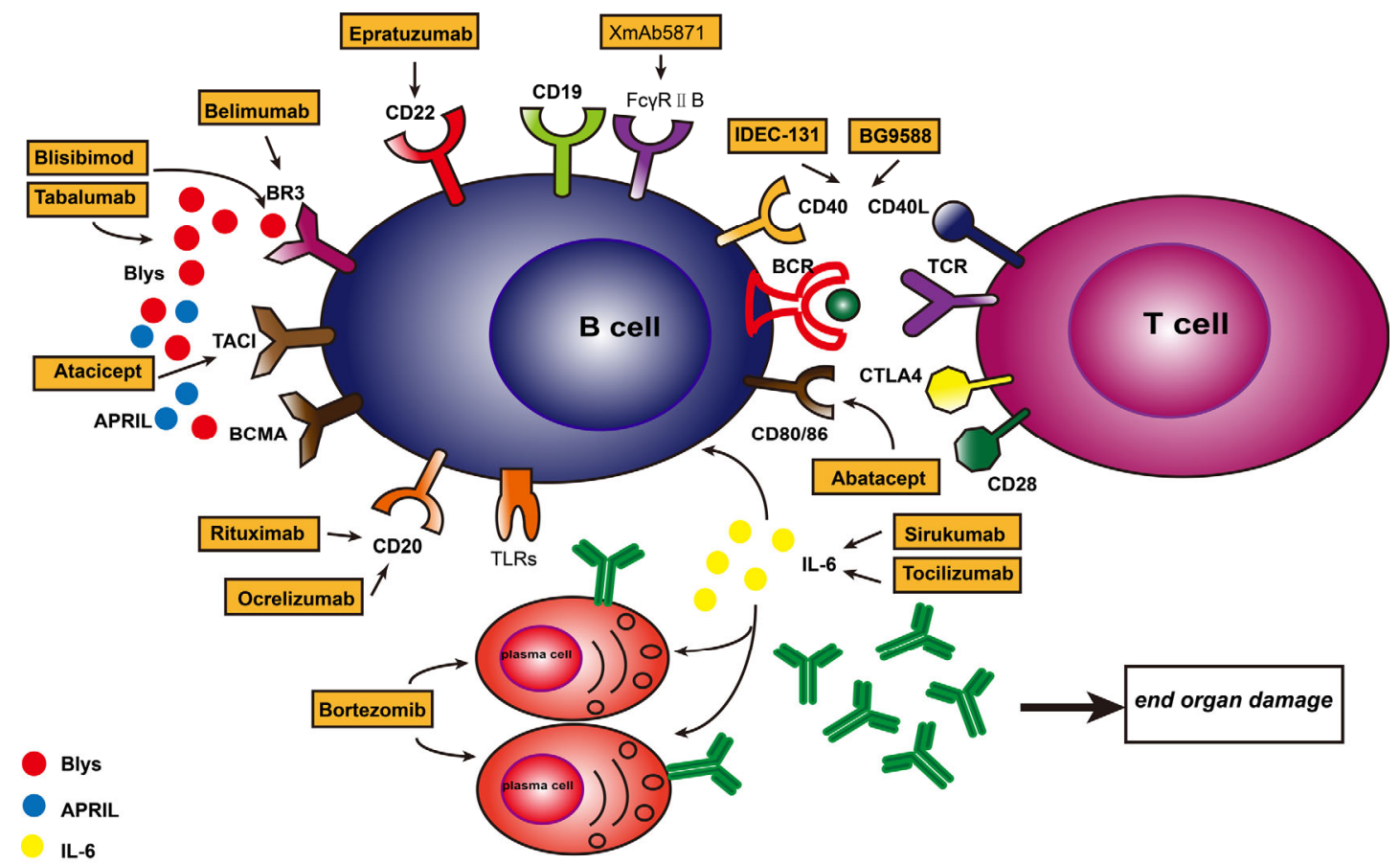

Figure 3 Biologics targeting B cell surface molecules. BLys, B lymphocyte stimulator; APRIL, a proliferation-inducing ligand; TACI, transmembrane activator-1 and calcium modulator and cyclophillin ligand-interactor; BCMA, B-cell maturation antigen; CTLA-4, cytotoxic T-lymphocyte- associated protein 4; CD40L, CD40 ligand; BCR, B cell receptor; TCR, T cell receptor. 


\subsection{B cell depletion}

Depletion of B cells protects lupus-prone mice (MRL.lpr or NZM 2328) from developing disease $[159,160]$. B-cell depletion is promising to induce disease amelioration by inhibiting autoantibody production and/or by interfering with other B-cell pathogenic functions. Ideal B cell target used for B cell depletion should be those molecules highly and exclusively expressed on B cell surface, not be sheared off into circulation, and expressed on both mature B cells and plasma cells so that could be targeted quickly and effectively.

\subsubsection{CD20-targeted therapy}

CD20 is a B cell lineage specific surface marker, expressed from early preB stage to mature B cells before differentiation into plasma cells. Antibodies binding to surface CD20 could deplete $\mathrm{B}$ cells in circulation by mechanisms including antibody-dependent cell-mediated cytotoxicity (ADCC), complement-dependent cytotoxicity (CDC), and direct induction of apoptosis [23]. Plasma cells don't express CD20 thus being insusceptible to anti-CD20 antibody. Although disease remission is always after ultimate elimination of autoantibodies, clinical improvement can be observed early before autoantibodies elimination. This is attributed to the abolishment of antibody-independent function of B cells. Current available CD20-targeted biologics include Rituximab (chimeric anti-CD20 with mouse derived variable regions and human IgG1 derived constant regions), Ocrelizumab and Ofatumumab (both are fully humanized anti-CD20).

Two major classic RCT (random controlled trial) studies of Rituximab in treating SLE, the exploratory phase II/III SLE evaluation of rituximab (EXPLORER) and the lupus nephritis assessment with rituximab (LUNAR) trial have not achieved their primary endpoints but certain beneficial effects can be observed in a proportion of the enrolled patients [161,162]. Among other small sample open clinical trials, encouraging results of Rituximab, such as steroid-sparing effects and histological improvement in treating LN, were reported [163-165]. The negative results of EXPLORER and LUNAR trials may mainly due to the imperfect study design such as the enrollment criteria of baseline severity, evaluation tools and endpoints settings, instead of inefficiency. What's more,the use of background mycophenolate mofetil (MMF) and high-dose steroids in these trials may have overwhelmed and masked the beneficial effect of Rituximab. Both guidelines from American College of Rheumatology (ACR) and European League against Rheumatism (EULAR) still suggest Rituximab be used in patients with active nephritis that fail to respond to conventional therapies based on real-life experience reports and open label studies that justify the efficacy of Rituximab [166,167].

A phase III clinical trial examining Ocrelizumab in treating patients with active LN also gained negative results, with no statistically significant superiority of both 400 and $1,000 \mathrm{mg}$ dosage versus placebo, although the overall response rates are numerically higher. The increased rate of serious infections in group of Ocrelizumab which may partly due to combined MMF has caused early termination [168].

Another humanized anti-CD20 mAb-Ofatumumab now is in clinical trial for B cell hematological malignancy and rheumatoid arthritis.

\subsection{Inactivating B cells}

\subsubsection{CD22-targeted therapy}

Epratuzumab is a humanized anti-CD22 antibody. An open-label study show Epratuzumab could reduce the circulating B cells by about $35 \%-40 \%$ and inhibit lupus disease activity, though serum levels of Ig and autoantibodies have not been significantly affected [169]. Recently published data from a phase I/II RCT study in Japanese show Epraruzumab could down-regulate CD22 expression as well as decrease total $\mathrm{B}$ cell count to a mild-to-moderate extent [170]. Two other RCT studies have been launched previously to evaluate the efficacy of Epratuzumab in SLE: ALLEVIATE-1 and ALLEVIATE-2. The results showed Epratuzumab could reduce British Isles Lupus Assessment Group (BILAG) scores and improve health-related quality of life (HRQOL) with reduced corticosteroid exposure. But premature termination due to cessation of drug supply led to a small sample of study population (only enrolled 90 patients), which maybe the cause of failure to achieve primary endpoint [171,172]. EMBLEM was a phase IIb RCT study targeting moderate to severe SLE patients and the results showed 2,400 mg (cumulative dose in four weeks) Epratuzumab was well tolerated with considerable clinical improvements. A higher proportion of responders than placebo group was observed [173], whereas both of the two phase III trials (EMBODY ${ }^{\mathrm{TM}}-1$ and -2 )have not meet their primary clinical efficacy endpoints, announced on 28 July, 2015. (http://www.ucb.com/ presscenter/News/article/UCBannounces-Phase-3-clinical-trial-program-for-epratuzumabin-Systemic-Lupus-Erythematosus-did-not-meet-primary-en dpoint-nbsp).

\subsubsection{FcrRIIB-targeted therapy}

$\mathrm{XmAb5871}$ is a genetically modified anti-CD19 mAb binding Fc $\gamma$ RIIB with high affinity, which could promote coengagement of FcyRIIB with BCR complex and amplify Fc $\gamma$ RIIB mediated inhibitory signal in activated B cells without depletion of $\mathrm{B}$ cells physically. In vitro study showed that XmAb5871 could reduce calcium influx and expression of CD80/CD86, and improve survival of lupus mice [174]. SM101, a soluble, recombinant non-glycosylated Fc $\gamma$ IIB receptor, functions to inhibit the binding of immune complexes to cell surface Fc $\gamma$ receptors and in turn 
prevent FcR signaling. Preliminary result from a phase IIa RCT is promising and encouraging. It seems prolonged SM101 treatment may lead to higher SLE response rate and patients with LN may benefit even more. (http:// acrabstracts.org/abstract/sm101-a-novel-recombinant-solublehuman-fcriib-receptor-in-the-treatment-of-systemiclupus-erythematosus-results-of-a-double-blind-placebocontrolled-multicenter-study/).

\subsubsection{Sirukumab/Olokizumab/Tocilizumab}

Both Sirukumab and Olokizumab are human anti-IL-6 monoclonal antibody, and Tocilizumab is a humanised anti-IL-6 receptor monoclonal antibody. All these three biologics could block IL-6 mediated effects. In patients with rheumatoid arthritis, significant improvement of disease activity by blocking IL-6 signaling has been reported [175-177]. But till now no concrete data about efficacy in patients with SLE have been obtained and phase I studies indicate that adverse effects such as neutropenia and infection are worthy of attention [178,179].

\subsection{Blocking crosstalk between $B$ cells and $T$ cells}

\subsubsection{Abatacept}

Abatacept is a fusion protein of CTLA4 (cytotoxic T-lymphocyte- associated protein 4) and IgG Fc that could block the interaction of CD28 and CD80/CD87 (B7), which is the co-stimulation signal for $T / B$ activation. The abatacept and cyclophosphamide combination: efficacy and safety study (ACCESS) trial did not demonstrate extra benefit of Abatacept on the basis of pulse cyclophosphamide followed by azathioprine [180]. Another phase II/III study enrolled patients with class III/IV LN, and showed improvement in serum immunological abnormalities and urine protein, although these studies did not meet primary endpoint of complete remission of LN [181].

\subsubsection{IDEC-131/BG9588}

Data from a phaseII RCT demonstrated no superiority in efficacy of IDEC-131 (a humanized anti-CD40L antibody) versus placebo in active SLE patients [182]. BG9588 is another humanized anti-CD40L antibody that blocks the interaction of CD40 and CD40L. In an open-label study on patients with proliferative LN, BG9588 therapy decreased anti-dsDNA antibodies by $50 \%$ two months after last treatment, increased serum complement 3 (C3) levels and eliminated hematuria. But serious thromboembolic events caused premature discontinuation [183].

\subsection{Affecting B cells growth and survival by blocking Blys}

\subsubsection{Belimumab}

Belimumab is a fully humanized monoclonal antibody against Blys. By blocking the binding of Blys to its receptors (mainly but not limited to BR3), Belimumab could resettle the apoptosis and maturation of B cells. It has received marketing approval for lupus treatment by the European Medicines Agency and USA, and it is the first biological medication officially approved for refractory SLE. Evidence comes primarily from two clinical trials, BLISS (the study of Belimumab in Subjects with SLE) 52 and BLISS 76 , both enrolled lupus patients with mild or moderate disease from different ethnic origins, excluding those with active nephritis or neuropsychiatric involvement, and both have met their endpoints [184-186]. Combined results show Belimumab is effective in treating musculoskeletal and mucocutaneous manifestations and slows down the worsening of the BILAG haematological and renal domains than placebo [186]. Post Hoc analysis suggests that patients with renal involvement especially those with serological activity or receiving $\mathrm{MMF}$ at baseline might also benefit from Belimumab [187]. In addition, Belimumab treatment helps to normalize complement levels and reduce anti-dsDNA antibodies and decrease certain B cells populations [188]. Responses more likely occurr in patients with higher disease activity [189].

\subsubsection{Atacicept}

Atacicept is a fusion protein of extracellular domain of TACI conjugated with human IgG Fc. Atacicept could block Blys and APRIL binding to TACI. Phase Ib placebo-controlled trial displayed biological activity of Atacicept in abating Ig levels and reducing total B cell numbers, in a dose-dependent manner [190]. Two phase II RCT of Atacicept in treating refractory rheumatoid arthritis displayed a rapid and profound decline of $\mathrm{Ig}$ and rheumatoid factor levels as well as circulating mature B cells and plasma cells in Atacicept group, although the primary endpoint of ACR20 was not met [191,192]. The biologic effects justify clinical trials in SLE. But a clinical trial aiming at LN patients was terminated prematurely because of serious infections associated with hypogammaglobulineamia which might be due to simultaneous MMF therapy [193]. In another SLE randomized trial, $150 \mathrm{mg}$ but not $75 \mathrm{mg}$ Atacicept showed benefits in reducing flare rates and prolonging prior-relapsing time compared to placebo, although both dosages have improved serological index [194]. Notably, $150 \mathrm{mg}$ arm was discontinued early because of two deaths.

\subsubsection{Blisibimod/Tabalumab}

Blisibimod (AMG 623) is a human IgG-Fc fused protein with high affinity to soluble and membrane-bound Blys. As for NZB/NZW F1 lupus mice, Blisibimod led to decreased $B$ cell number and improvement of disease activity [195]. In PEARL-SC study, a phase II/III trial of Blisibimod which enrolled moderate to severe SLE patients, reduced proteinuria and decreased $\mathrm{B}$ cell number, as well as restoration 
of serum C3 levels and lowering of anti-dsDNA antibodies have been observed with a favorable outcome on cumulative severe flare in Blisibimod therapeutic group [196]. Tabalumab is another human neutralizing monoclonal antibody targeting both membrane and soluble Blys [197]. Although in rheumatoid arthritis, phase II clinical trials of Tabalumab show inconsistent results [198-200] and phase III RCT is terminated due to lack of efficacy [201,202], recently published data from two multicentre phase III RCT of Tabalumab in treating moderate to severe SLE (ILLUMINATE-1 and -2) (NCT00111306 and NCT00383214) seems promising. Both trials show significantly improvement in serum biomarkers of disease activity like anti-dsDNA and C3. But the primary endpoint of SLE responder index 5 has been only met in ILLUMINATE-2 at the dose of $120 \mathrm{mg} \mathrm{Q} 2 \mathrm{w}$, but not met at the dose of $120 \mathrm{mg}$ Q4w and in ILLUMINATE-1 study. These trials suggest that the dosing strategy and the demographic characteristics have important influence on the therapeutic effects, and regime for different patients should be optimized [203,204].

\subsection{Proteasome inhibitor}

Long-lived plasma cells, being capable of continuing producing autoantibodies and resistant to conventional treatments and anti-CD20 biologics, are responsible for refractory disease and flare. Bortezomib, a proteasome inhibitor that has been approved for multiple myeloma treatment, shows effects in efficiently depleting long-lived plasma cells, ameliorating nephritis, reducing disease activity and prolonging survival in lupus mice $[205,206]$. The mechanism is explored and inhibition of IFN $\alpha$ production by suppressing TLR-activated plasmacytoid DC is proposed, probably through interrupting the translocation and intracellular trafficking of TLR [207,208]. Data from non-controlled small sample clinical trial indicates Bortezomib could significantly reduce anti-dsDNA titers and plasma cell numbers as well as disease activity [209]. But these effects could not perpetuate, and the adverse effects occur frequently, leading to discontinuation in more than half of the patients. Further randomized controlled well-designed studies are needed for evaluation of its application in SLE.

\section{Perspective of SLE targeted therapy focusing on $B$ cells}

B cell-targeting therapy seems to be a promising approach in the treatment of SLE, but more effective agent and appropriate enrollment criteria and further elucidation of $\mathrm{B}$ cells pathogenesis in SLE are needed. Strictly speaking, all these so far developed targeting therapy do not accurately "target" pathogenic B cells without affecting "good" B cell populations. Thus we should be always vigilant about the increased risks of infection and other adverse effects. Moreover, due to the complicated mechanisms and various components involved in the pathogenesis of SLE, no single drug will be appropriate for all SLE patients at each stage of disease course. More precise targeting therapy and rationally combined medications should be explored in the future.

The authors declare that they have no conflict of interest.

1 Rahman A, Isenberg DA. Systemic lupus erythematosus. N Engl J Med, 2008, 358: 929-939

2 Jacob N, Stohl W. Autoantibody-dependent and autoantibodyindependent roles for B cells in systemic lupus erythematosus: past, present, and future. Autoimmunity, 2010, 43: 84-97

3 Yee CS, Hussein H, Skan J, Bowman S, Situnayake D, Gordon C. Association of damage with autoantibody profile, age, race, sex and disease duration in systemic lupus erythematosus. Rheumatology (Oxford), 2003, 42: 276-279

4 Yaniv G, Twig G, Shor DB, Furer A, Sherer Y, Mozes O, Komisar O, Slonimsky E, Klang E, Lotan E, Welt M, Marai I, Shina A, Amital $\mathrm{H}$, Shoenfeld Y. A volcanic explosion of autoantibodies in systemic lupus erythematosus: a diversity of 180 different antibodies found in SLE patients. Autoimmun Rev, 2015, 14: 75-79

5 Cozzani E, Drosera M, Gasparini G, Parodi A. Serology of lupus erythematosus: correlation between immunopathological features and clinical aspects. Autoimmune Dis, 2014, 2014: 321359

6 Odendahl M, Jacobi A, Hansen A, Feist E, Hiepe F, Burmester GR, Lipsky PE, Radbruch A, Dörner T. Disturbed peripheral B lymphocyte homeostasis in systemic lupus erythematosus. J Immunol, 2000, 165: 5970-5979

7 Anolik JH. B cell biology: implications for treatment of systemic lupus erythematosus. Lupus, 2013, 22: 342-349

8 Ahmed S, Anolik JH. B-cell biology and related therapies in systemic lupus erythematosus. Rheum Dis Clin North Am, 2010, 36: 109-130, viii-ix

9 Migliorini P, Baldini C, Rocchi V, Bombardieri S. Anti-Sm and anti-RNP antibodies. Autoimmunity, 2005, 38: 47-54

10 Mahler M. Sm peptides in differentiation of autoimmune diseases. Adv Clin Chem, 2011, 54: 109-128

11 Bastian HM, Alarcon GS, Roseman JM, McGwin G Jr., Vila LM, Fessler BJ, Reveille JD, LUMINA Study Group. Systemic lupus erythematosus in a multiethnic US cohort (LUMINA) XL II: factors predictive of new or worsening proteinuria. Rheumatology (Oxford), 2007, 46: 683-689

12 Bastian HM, Roseman JM, McGwin G Jr., Alarcon GS, Friedman AW, Fessler BJ, Baethge BA, Reveille JD, LUMINA Study Group. Systemic lupus erythematosus in three ethnic groups. XII. Risk factors for lupus nephritis after diagnosis. Lupus, 2002, 11: 152-160

13 Briani C, Lucchetta M, Ghirardello A, Toffanin E, Zampieri S, Ruggero S, Scarlato M, Quattrini A, Bassi N, Ermani M, Battistin L, Doria A. Neurolupus is associated with anti-ribosomal $\mathrm{P}$ protein antibodies: an inception cohort study. J Autoimmun, 2009, 32: 79-84

14 Karassa FB, Afeltra A, Ambrozic A, Chang DM, De Keyser F, Doria A, Galeazzi M, Hirohata S, Hoffman IE, Inanc M, Massardo L, Mathieu A, Mok CC, Morozzi G, Sanna G, Spindler AJ, Tzioufas AG, Yoshio T, Ioannidis JP. Accuracy of anti-ribosomal P protein antibody testing for the diagnosis of neuropsychiatric systemic lupus erythematosus: an international meta-analysis. Arthritis Rheum, 2006, 54: 312-324

15 Mond CB, Peterson MG, Rothfield NF. Correlation of anti-Ro antibody with photosensitivity rash in systemic lupus erythematosus patients. Arthritis Rheum, 1989, 32: 202-204

16 Fukuda MV, Lo SC, de Almeida CS, Shinjo SK. Anti-Ro antibody and cutaneous vasculitis in systemic lupus erythematosus. Clin Rheumatol, 2009, 28: 301-304 
17 Buyon JP, Winchester R. Congenital complete heart block. A human model of passively acquired autoimmune injury. Arthritis Rheum, 1990, 33: 609-614

18 Chan OT, Hannum LG, Haberman AM, Madaio MP, Shlomchik MJ. A novel mouse with $\mathrm{B}$ cells but lacking serum antibody reveals an antibody-independent role for B cells in murine lupus. J Exp Med, 1999, 189: 1639-1648

19 Chan OT, Madaio MP, Shlomchik MJ. B cells are required for lupus nephritis in the polygenic, Fas-intact MRL model of systemic autoimmunity. J Immunol, 1999, 163: 3592-3596

20 Chan OT, Madaio MP, Shlomchik MJ. The central and multiple roles of B cells in lupus pathogenesis. Immunol Rev, 1999, 169: 107-121

21 Crawford A, Macleod M, Schumacher T, Corlett L, Gray D. Primary $\mathrm{T}$ cell expansion and differentiation in vivo requires antigen presentation by B cells. J Immunol, 2006, 176: 3498-3506

22 Chan O, Shlomchik MJ. A new role for B cells in systemic autoimmunity: $\mathrm{B}$ cells promote spontaneous $\mathrm{T}$ cell activation in MRL-lpr/lpr mice. J Immunol, 1998, 160: 51-59

23 Stohl W. Future prospects in biologic therapy for systemic lupus erythematosus. Nat Rev Rheumatol, 2013, 9: 705-720

24 Quách TD, Manjarrez-Orduño N, Adlowitz DG, Silver L, Yang H, Wei C, Milner EC, Sanz I. Anergic responses characterize a large fraction of human autoreactive naive B cells expressing low levels of surface IgM. J Immunol, 2011, 186: 4640-4648

25 Rodriguez-Bayona B, Ramos-Amaya A, Perez-Venegas JJ, Rodriguez C, Brieva JA. Decreased frequency and activated phenotype of blood CD27 IgD IgM B lymphocytes is a permanent abnormality in systemic lupus erythematosus patients. Arthritis Res Ther, 2010, 12: R108

26 Yurasov S, Wardemann H, Hammersen J, Tsuiji M, Meffre E, Pascual V, Nussenzweig MC. Defective B cell tolerance checkpoints in systemic lupus erythematosus. J Exp Med, 2005, 201: 703-711

27 Blair PA, Norena LY, Flores-Borja F, Rawlings DJ, Isenberg DA, Ehrenstein MR, Mauri C. CD $19^{+} \mathrm{CD} 24^{\text {hi }} \mathrm{CD} 38^{\text {hi }}$ B cells exhibit regulatory capacity in healthy individuals but are functionally impaired in systemic Lupus Erythematosus patients. Immunity, 2010, 32: $129-140$

28 Gao N, Dresel J, Eckstein V, Gellert R, Storch H, Venigalla RK, Schwenger V, Max R, Blank N, Lorenz HM, Tretter T. Impaired suppressive capacity of activation-induced regulatory $\mathrm{B}$ cells in systemic lupus erythematosus. Arthritis Rheumatol, 2014, 66: 2849-2861

29 Pillai S, Mattoo H, Cariappa A. B cells and autoimmunity. Curr Opin Immunol, 2011, 23: 721-731

30 Wardemann H, Yurasov S, Schaefer A, Young JW, Meffre E, Nussenzweig MC. Predominant autoantibody production by early human B cell precursors. Science, 2003, 301: 1374-1377

31 Arce E, Jackson DG, Gill MA, Bennett LB, Banchereau J, Pascual V. Increased frequency of pre-germinal center B cells and plasma cell precursors in the blood of children with systemic lupus erythematosus. J Immunol, 2001, 167: 2361-2369

32 Lee J, Kuchen S, Fischer R, Chang S, Lipsky PE. Identification and characterization of a human CD5+ pre-naive B cell population. $\mathrm{J}$ Immunol, 2009, 182: 4116-4126

33 Jacobi AM, Odendahl M, Reiter K, Bruns A, Burmester GR, Radbruch A, Valet G, Lipsky PE, Dörner T. Correlation between circulating CD27high plasma cells and disease activity in patients with systemic lupus erythematosus. Arthritis Rheum, 2003, 48: 1332-1342

34 Shirota Y, Yarboro C, Fischer R, Pham TH, Lipsky P, Illei GG. Impact of anti-interleukin-6 receptor blockade on circulating $\mathrm{T}$ and $\mathrm{B}$ cell subsets in patients with systemic lupus erythematosus. Ann Rheum Dis, 2013, 72: 118-128

35 Wahren-Herlenius M, Dorner T. Immunopathogenic mechanisms of systemic autoimmune disease. Lancet, 2013, 382: 819-831

36 Fillatreau S, Sweenie CH, McGeachy MJ, Gray D, Anderton SM. B cells regulate autoimmunity by provision of IL-10. Nat Immunol, 2002, 3: 944-950

37 Yanaba K, Bouaziz JD, Haas KM, Poe JC, Fujimoto M, Tedder TF.
A regulatory $\mathrm{B}$ cell subset with a unique CD1dhiCD5+ phenotype controls T cell-dependent inflammatory responses. Immunity, 2008, 28: 639-650

38 Iwata Y, Matsushita T, Horikawa M, Dilillo DJ, Yanaba K, Venturi GM, Williams AD, Hall RP, St Clair EW, Tedder TF. Characterization of a rare IL-10-competent B-cell subset in humans that parallels mouse regulatory B10 cells. Blood, 2011, 117: 530-541

39 Watanabe R, Ishiura N, Nakashima H, Kuwano Y, Okochi H, Tamaki K, Sato S, Tedder TF, Fujimoto M. Regulatory B cells (B10 cells) have a suppressive role in murine lupus: CD19 and B10 cell deficiency exacerbates systemic autoimmunity. J Immunol, 2010, 184: 4801-4809

40 Yin Z, Bahtiyar G, Zhang N, Liu L, Zhu P, Robert ME, McNiff J, Madaio MP, Craft J. IL-10 regulates murine lupus. J Immunol, 2002, 169: 2148-2155

41 Llorente L, Richaud-Patin Y, Garcia-Padilla C, Claret E, Jakez-Ocampo J, Cardiel MH, Alcocer-Varela J, Grangeot-Keros L, Alarcón-Segovia D, Wijdenes J, Galanaud P, Emilie D. Clinical and biologic effects of anti-interleukin-10 monoclonal antibody administration in systemic lupus erythematosus. Arthritis Rheum, 2000, 43: 1790-1800

42 Taher TE, Muhammad HA, Bariller E, Flores-Borja F, Renaudineau Y, Isenberg DA, Mageed RA. B-lymphocyte signalling abnormalities and lupus immunopathology. Int Rev Immunol, 2013, 32: 428-444

43 Drake CG, Kotzin BL. Genetic and immunological mechanisms in the pathogenesis of systemic lupus erythematosus. Curr Opin Immunol, 1992, 4: 733-740

44 Jiang Y, Hirose S, Sanokawa-Akakura R, Abe M, Mi X, Li N, Miura Y, Shirai J, Zhang D, Hamano Y, Shirai T. Genetically determined aberrant down-regulation of FcgammaRIIB1 in germinal center B cells associated with hyper-IgG and IgG autoantibodies in murine systemic lupus erythematosus. Int Immunol, 1999, 11: 1685-1691

45 Meyers G, Ng YS, Bannock JM, Lavoie A, Walter JE, Notarangelo LD, Kilic SS, Aksu G, Debré M, Rieux-Laucat F, Conley ME, Cunningham-Rundles C, Durandy A, Meffre E. Activation-induced cytidine deaminase (AID) is required for B-cell tolerance in humans. Proc Natl Acad Sci USA, 2011, 108: 11554-11559

46 Vaughn SE, Kottyan LC, Munroe ME, Harley JB. Genetic susceptibility to lupus: the biological basis of genetic risk found in B cell signaling pathways. J Leukoc Biol, 2012, 92: 577-591

47 Wakeland EK, Liu K, Graham RR, Behrens TW. Delineating the genetic basis of systemic lupus erythematosus. Immunity, 2001, 15: 397-408

48 Kumar KR, Li L, Yan M, Bhaskarabhatla M, Mobley AB, Nguyen C, Mooney JM, Schatzle JD, Wakeland EK, Mohan C. Regulation of B cell tolerance by the lupus susceptibility gene Ly108. Science, 2006, 312: 1665-1669

49 Zhang W, Shi Q, Xu X, Chen H, Lin W, Zhang F, Zeng X, Zhang X, Ba D, He W. Aberrant CD40-induced NF-kappaB activation in human lupus B lymphocytes. PLoS One, 2012, 7: e41644

50 Grammer AC, Slota R, Fischer R, Gur H, Girschick H, Yarboro C, Illei GG, Lipsky PE. Abnormal germinal center reactions in systemic lupus erythematosus demonstrated by blockade of CD154-CD40 interactions. J Clin Invest, 2003, 112: 1506-1520

51 Desai-Mehta A, Lu L, Ramsey-Goldman R, Datta SK. Hyperexpression of CD40 ligand by B and T cells in human lupus and its role in pathogenic autoantibody production. J Clin Invest, 1996, 97: 2063-2073

52 Kishi Y, Aiba Y, Higuchi T, Furukawa K, Tokuhisa T, Takemori T, Tsubata T. Augmented antibody response with premature germinal center regression in CD40L transgenic mice. J Immunol, 2010, 185: 211-219

53 Kawabe T, Naka T, Yoshida K, Tanaka T, Fujiwara H, Suematsu S, Yoshida N, Kishimoto T, Kikutani H. The immune responses in CD40-deficient mice: impaired immunoglobulin class switching and germinal center formation. Immunity, 1994, 1: 167-178

54 Grewal IS, Xu J, Flavell RA. Impairment of antigen-specific T-cell priming in mice lacking CD40 ligand. Nature, 1995, 378: 617-620

55 Higuchi T, Aiba Y, Nomura T, Matsuda J, Mochida K, Suzuki M, 
Kikutani H, Honjo T, Nishioka K, Tsubata T. Cutting Edge: ectopic expression of CD40 ligand on B cells induces lupus-like autoimmune disease. J Immunol, 2002, 168: 9-12

56 Garaud S, Le Dantec C, Jousse-Joulin S, Hanrotel-Saliou C, Saraux A, Mageed RA, Youinou P, Renaudineau Y. IL-6 modulates CD5 expression in B cells from patients with lupus by regulating DNA methylation. J Immunol, 2009, 182: 5623-5632

57 Tedder TF, Tuscano J, Sato S, Kehrl JH. CD22, a B lymphocyte-specific adhesion molecule that regulates antigen receptor signaling. Annu Rev Immunol, 1997, 15: 481-504

58 Tedder TF, Poe JC, Haas KM. CD22: a multifunctional receptor that regulates B lymphocyte survival and signal transduction. Adv Immunol, 2005, 88: 1-50

59 O'Keefe TL, Williams GT, Davies SL, Neuberger MS. Hyperresponsive B cells in CD22-deficient mice. Science, 1996, 274 : 798-801

60 Yarkoni Y, Fischel R, Kat I, Yachimovich-Cohen N, Eilat D. Peripheral B cell receptor editing may promote the production of high-affinity autoantibodies in CD22-deficient mice. Eur J Immunol, 2006, 36: 2755-2767

61 Fleischer V, Sieber J, Fleischer SJ, Shock A, Heine G, Daridon C, Dörner T. Epratuzumab inhibits the production of the proinflammatory cytokines IL-6 and TNF-alpha, but not the regulatory cytokine IL-10, by B cells from healthy donors and SLE patients. Arthritis Res Ther, 2015, 17: 185

62 Dorner T, Shock A, Goldenberg DM, Lipsky PE. The mechanistic impact of CD22 engagement with epratuzumab on B cell function: Implications for the treatment of systemic lupus erythematosus. Autoimmun Rev, 2015, doi: 10.1016/j.autrev.2015.07.013

63 Rossi EA, Chang CH, Goldenberg DM. Anti-CD22/CD20 Bispecific antibody with enhanced trogocytosis for treatment of Lupus. PLoS One, 2014, 9: e98315

64 Flores-Borja F, Kabouridis PS, Jury EC, Isenberg DA, Mageed RA. Altered lipid raft-associated proximal signaling and translocation of CD45 tyrosine phosphatase in B lymphocytes from patients with systemic lupus erythematosus. Arthritis Rheum, 2007, 56: 291-302

65 Katagiri T, Ogimoto M, Hasegawa K, Arimura Y, Mitomo K, Okada M, Clark MR, Mizuno K, Yakura H. CD45 negatively regulates lyn activity by dephosphorylating both positive and negative regulatory tyrosine residues in immature B cells. J Immunol, 1999, 163: 1321-1326

66 Saunders AE, Johnson P. Modulation of immune cell signalling by the leukocyte common tyrosine phosphatase, CD45. Cell Signal, 2010, 22: 339-348

67 Hippen KL, Buhl AM, D’Ambrosio D, Nakamura K, Persin C, Cambier JC. Fc gammaRIIB1 inhibition of BCR-mediated phosphoinositide hydrolysis and $\mathrm{Ca}^{2+}$ mobilization is integrated by CD19 dephosphorylation. Immunity, 1997, 7: 49-58

68 Nakamura K, Malykhin A, Coggeshall KM. The Src homology 2 domain-containing inositol 5-phosphatase negatively regulates Fcgamma receptor-mediated phagocytosis through immunoreceptor tyrosine-based activation motif-bearing phagocytic receptors. Blood, 2002, 100: 3374-3382

69 Enyedy EJ, Mitchell JP, Nambiar MP, Tsokos GC. Defective FcgammaRIIb1 signaling contributes to enhanced calcium response in B cells from patients with systemic lupus erythematosus. Clin Immunol, 2001, 101: 130-135

70 Mackay M, Stanevsky A, Wang T, Aranow C, Li M, Koenig S, Ravetch JV, Diamond B. Selective dysregulation of the FcgammaIIB receptor on memory B cells in SLE. J Exp Med, 2006, 203: 2157-2164

71 Tiller T, Kofer J, Kreschel C, Busse CE, Riebel S, Wickert S, Oden F, Mertes MM, Ehlers M, Wardemann H. Development of self-reactive germinal center B cells and plasma cells in autoimmune Fc gammaRIIB-deficient mice. J Exp Med, 2010, 207: 2767-2778

72 Fukuyama H, Nimmerjahn F, Ravetch JV. The inhibitory Fcgamma receptor modulates autoimmunity by limiting the accumulation of immunoglobulin G+ anti-DNA plasma cells. Nat Immunol, 2005, 6: 99-106
73 McGaha TL, Sorrentino B, Ravetch JV. Restoration of tolerance in lupus by targeted inhibitory receptor expression. Science, 2005, 307: 590-593

74 Floto RA, Clatworthy MR, Heilbronn KR, Rosner DR, MacAry PA, Rankin A, Lehner PJ, Ouwehand WH, Allen JM, Watkins NA, Smith KG. Loss of function of a lupus-associated FcgammaRIIb polymorphism through exclusion from lipid rafts. Nat Med, 2005, 11: 1056-1058

75 Kono H, Kyogoku C, Suzuki T, Tsuchiya N, Honda H, Yamamoto K, Tokunaga K, Honda Z. FcgammaRIIB Ile232Thr transmembrane polymorphism associated with human systemic lupus erythematosus decreases affinity to lipid rafts and attenuates inhibitory effects on B cell receptor signaling. Hum Mol Genet, 2005, 14: 2881-2892

76 Finck BK, Linsley PS, Wofsy D. Treatment of murine lupus with CTLA4Ig. Science, 1994, 265: 1225-1227

77 Pugh-Bernard AE, Cambier JC. B cell receptor signaling in human systemic lupus erythematosus. Curr Opin Rheumatol, 2006, 18: $451-455$

78 Liu K, Mohan C. Altered B-cell signaling in lupus. Autoimmun Rev, 2009, 8: 214-218

79 Peng SL. Altered T and B lymphocyte signaling pathways in lupus. Autoimmun Rev, 2009, 8: 179-183

80 Tolar P, Sohn HW, Pierce SK. The initiation of antigen-induced B cell antigen receptor signaling viewed in living cells by fluorescence resonance energy transfer. Nat Immunol, 2005, 6: 1168-1176

81 Kurosaki T, Shinohara H, Baba Y. B cell signaling and fate decision. Annu Rev Immunol, 2010, 28: 21-55

82 Kurosaki T. Genetic analysis of B cell antigen receptor signaling. Annu Rev Immunol, 1999, 17: 555-559

83 Khan WN. B cell receptor and BAFF receptor signaling regulation of B cell homeostasis. J Immunol, 2009, 183: 3561-3567

$84 \mathrm{Xu} \mathrm{Y,} \mathrm{Harder} \mathrm{KW,} \mathrm{Huntington} \mathrm{ND,} \mathrm{Hibbs} \mathrm{ML,} \mathrm{Tarlinton} \mathrm{DM.} \mathrm{Lyn}$ tyrosine kinase: accentuating the positive and the negative. Immunity, 2005, 22: 9-18

85 Liossis SN, Melissaropoulos K. Molecular abnormalities of the B cell in systemic lupus erythematosus are candidates for functional inhibition treatments. Expert Opin Pharmacother, 2014, 15: 833-840

86 Nishizumi H, Horikawa K, Mlinaric-Rascan I, Yamamoto T. A double-edged kinase Lyn: a positive and negative regulator for antigen receptor-mediated signals. J Exp Med, 1998, 187: 1343-1348

87 Hibbs ML, Tarlinton DM, Armes J, Grail D, Hodgson G, Maglitto R, Stacker SA, Dunn AR. Multiple defects in the immune system of Lyn-deficient mice, culminating in autoimmune disease. Cell, 1995, 83: 301-311

88 Lamagna C, Hu Y, DeFranco AL, Lowell CA. B cell-specific loss of Lyn kinase leads to autoimmunity. J Immunol, 2014, 192: 919-928

89 Nishizumi H, Taniuchi I, Yamanashi Y, Kitamura D, Ilic D, Mori S, Watanabe T, Yamamoto T. Impaired proliferation of peripheral B cells and indication of autoimmune disease in lyn-deficient mice. Immunity, 1995, 3: 549-560

90 Tsantikos E, Maxwell MJ, Kountouri N, Harder KW, Tarlinton DM, Hibbs ML. Genetic interdependence of Lyn and negative regulators of B cell receptor signaling in autoimmune disease development. J Immunol, 2012, 189: 1726-1736

91 Flores-Borja F, Kabouridis PS, Jury EC, Isenberg DA, Mageed RA. Decreased Lyn expression and translocation to lipid raft signaling domains in B lymphocytes from patients with systemic lupus erythematosus. Arthritis Rheum, 2005, 52: 3955-3965

92 Liossis SN, Solomou EE, Dimopoulos MA, Panayiotidis P, Mavrikakis MM, Sfikakis PP. B-cell kinase lyn deficiency in patients with systemic lupus erythematosus. J Investig Med, 2001, 49: $157-165$

93 Liu Y, Dong J, Mu R, Gao Y, Tan X, Li Y, Li Z, Yang G. MicroRNA-30a promotes $B$ cell hyperactivity in patients with systemic lupus erythematosus by direct interaction with Lyn. Arthritis Rheum, 2013, 65: 1603-1611

94 Hibbs ML, Harder KW, Armes J, Kountouri N, Quilici C, Casagranda F, Dunn AR, Tarlinton DM. Sustained activation of Lyn tyrosine kinase in vivo leads to autoimmunity. J Exp Med, 2002, 196: 
$1593-1604$

95 Suarez-Fueyo A, Barber DF, Martinez-Ara J, Zea-Mendoza AC, Carrera AC. Enhanced phosphoinositide 3-kinase delta activity is a frequent event in systemic lupus erythematosus that confers resistance to activation-induced T cell death. J Immunol, 2011, 187: 2376-2385

96 Wu XN, Ye YX, Niu JW, Li Y, Li X, You X, Chen H, Zhao LD, Zeng XF, Zhang FC, Tang FL, He W, Cao XT, Zhang X, Lipsky PE. Defective PTEN regulation contributes to B cell hyperresponsiveness in systemic lupus erythematosus. Sci Transl Med, 2014, 6: 246 ra99

97 Okkenhaug K, Bilancio A, Farjot G, Priddle H, Sancho S, Peskett E, Pearce W, Meek SE, Salpekar A, Waterfield MD, Smith AJ, Vanhaesebroeck B. Impaired B and T cell antigen receptor signaling in p110delta PI 3-kinase mutant mice. Science, 2002, 297: 1031-1034

98 Omori SA, Cato MH, Anzelon-Mills A, Puri KD, Shapiro-Shelef M, Calame K, Rickert RC. Regulation of class-switch recombination and plasma cell differentiation by phosphatidylinositol 3-kinase signaling. Immunity, 2006, 25: 545-557

99 Puri KD, Gold MR. Selective inhibitors of phosphoinositide 3-kinase delta: modulators of B-cell function with potential for treating autoimmune inflammatory diseases and B-cell malignancies. Front Immunol, 2012, 3: 256

100 Omori SA, Rickert RC. Phosphatidylinositol 3-kinase (PI3K) signaling and regulation of the antibody response. Cell Cycle, 2007, 6: 397-402

101 Maxwell MJ, Tsantikos E, Kong AM, Vanhaesebroeck B, Tarlinton DM, Hibbs ML. Attenuation of phosphoinositide 3-kinase delta signaling restrains autoimmune disease. J Autoimmun, 2012, 38: 381-391

102 Barber DF, Bartolomé A, Hernandez C, Flores JM, Redondo C, Fernandez-Arias C, Camps M, Rückle T, Schwarz MK, Rodríguez S, Martinez-A C, Balomenos D, Rommel C, Carrera AC. PI3Kgamma inhibition blocks glomerulonephritis and extends lifespan in a mouse model of systemic lupus. Nat Med, 2005, 11: 933-935

103 Ding C, Yan J. Regulation of autoreactive B cells: checkpoints and activation. Arch Immunol Ther Exp (Warsz), 2007, 55: 83-89

104 Tiegs SL, Russell DM, Nemazee D. Receptor editing in self-reactive bone marrow B cells. J Exp Med, 1993, 177: 1009-1020

105 Gay D, Saunders T, Camper S, Weigert M. Receptor editing: an approach by autoreactive B cells to escape tolerance. J Exp Med, 1993, 177: 999-1008

106 Zouali M. Transcriptional and metabolic pre-B cell receptor-mediated checkpoints: implications for autoimmune diseases. Mol Immunol, 2014, 62: 315-320

107 Keenan RA, De Riva A, Corleis B, Hepburn L, Licence S, Winkler TH, Mårtensson IL. Censoring of autoreactive B cell development by the pre-B cell receptor. Science, 2008, 321: 696-699

108 Lian ZX, Kita H, Okada T, Hsu T, Shultz LD, Dorshkind K, Ansari AA, Ikehara S, Naiki M, Gershwin ME. Increased frequency of pre-pro B cells in the bone marrow of New Zealand Black (NZB) mice: implications for a developmental block in $\mathrm{B}$ cell differentiation. Dev Immunol, 2002, 9: 35-45

109 Hamel KM, Liarski VM, Clark MR. Germinal center B-cells. Autoimmunity, 2012, 45: 333-347

110 Cappione A 3rd, Anolik JH, Pugh-Bernard A, Barnard J, Dutcher P, Silverman G, Sanz I. Germinal center exclusion of autoreactive B cells is defective in human systemic lupus erythematosus. J Clin Invest, 2005, 115: 3205-3216

111 Caron G, Le Gallou S, Lamy T, Tarte K, Fest T. CXCR4 expression functionally discriminates centroblasts versus centrocytes within human germinal center B cells. J Immunol, 2009, 182: 7595-7602

112 Allen CD, Ansel KM, Low C, Lesley R, Tamamura H, Fujii N, Cyster JG. Germinal center dark and light zone organization is mediated by CXCR4 and CXCR5. Nat Immunol, 2004, 5: 943-952

113 Vinuesa CG, Sanz I, Cook MC. Dysregulation of germinal centres in autoimmune disease. Nat Rev Immunol, 2009, 9: 845-857

114 Wang A, Guilpain P, Chong BF, Chouzenoux S, Guillevin L, Du Y, Zhou XJ, Lin F, Fairhurst AM, Boudreaux C, Roux C, Wakeland EK,
Davis LS, Batteux F, Mohan C. Dysregulated expression of CXCR4/CXCL12 in subsets of patients with systemic lupus erythematosus. Arthritis Rheum, 2010, 62: 3436-3446

115 Craft JE. Follicular helper $\mathrm{T}$ cells in immunity and systemic autoimmunity. Nat Rev Rheumatol, 2012, 8: 337-347

116 Dong W, Zhu P, Wang Y, Wang Z. Follicular helper T cells in systemic lupus erythematosus: a potential therapeutic target. Autoimmun Rev, 2011, 10: 299-304

117 Xu H, Liu J, Cui X, Zuo Y, Zhang Z, Li Y, Tao R, Li Y, Pang J. Increased frequency of circulating follicular helper $\mathrm{T}$ cells in lupus patients is associated with autoantibody production in a CD40L-dependent manner. Cell Immunol, 2015, 295: 46-51

118 Kim YU, Lim H, Jung HE, Wetsel RA, Chung Y. Regulation of autoimmune germinal center reactions in Lupus-Prone BXD2 mice by follicular helper T Cells. PLoS One, 2015, 10: e0120294

119 Choi JY, Ho JH, Pasoto SG, Bunin V, Kim ST, Carrasco S, Borba EF, Gonçalves CR, Costa PR, Kallas EG, Bonfa E, Craft J. Circulating follicular helper-like $\mathrm{T}$ cells in systemic lupus erythematosus: association with disease activity. Arthritis Rheumatol, 2015, 67: 988-999

120 Vogelzang A, McGuire HM, Yu D, Sprent J, Mackay CR, King C. A fundamental role for interleukin-21 in the generation of $\mathrm{T}$ follicular helper cells. Immunity, 2008, 29: 127-137

121 Wang L, Zhao P, Ma L, Shan Y, Jiang Z, Wang J, Jiang Y. Increased interleukin 21 and follicular helper T-like cells and reduced interleukin 10+ B cells in patients with new-onset systemic lupus erythematosus. J Rheumatol, 2014, 41: 1781-1792

122 Deng XM, Yan SX, Wei W. IL-21 acts as a promising therapeutic target in systemic lupus erythematosus by regulating plasma cell differentiation. Cell Mol Immunol, 2015, 12: 31-39

123 Giltiay NV, Chappell CP, Clark EA. B-cell selection and the development of autoantibodies. Arthritis Res Ther, 2012, 14 Suppl 4: S1

124 Isnardi I, Ng YS, Srdanovic I, Motaghedi R, Rudchenko S, von Bernuth H, Zhang SY, Puel A, Jouanguy E, Picard C, Garty BZ, Camcioglu Y, Doffinger R, Kumararatne D, Davies G, Gallin JI, Haraguchi S, Day NK, Casanova JL, Meffre E. IRAK-4- and MyD88-dependent pathways are essential for the removal of developing autoreactive B cells in humans. Immunity, 2008, 29: 746-757

125 Soni C, Wong EB, Domeier PP, Khan TN, Satoh T, Akira S, Rahman ZS. B cell-intrinsic TLR7 signaling is essential for the development of spontaneous germinal centers. J Immunol, 2014, 193: 4400-4414

126 Sieber J, Daridon C, Fleischer SJ, Fleischer V, Hiepe F, Alexander T, Heine G, Burmester GR, Fillatreau S, Dörner T. Active systemic lupus erythematosus is associated with a reduced cytokine production by B cells in response to TLR9 stimulation. Arthritis Res Ther, 2014, 16: 477

127 Mackay F, Browning JL. BAFF: a fundamental survival factor for B cells. Nat Rev Immunol, 2002, 2: 465-475

128 Schneider P, MacKay F, Steiner V, Hofmann K, Bodmer JL, Holler N, Ambrose C, Lawton P, Bixler S, Acha-Orbea H, Valmori D, Romero P, Werner-Favre C, Zubler RH, Browning JL, Tschopp J. BAFF, a novel ligand of the tumor necrosis factor family, stimulates B cell growth. J Exp Med, 1999, 189: 1747-1756

129 O'Connor BP, Raman VS, Erickson LD, Cook WJ, Weaver LK, Ahonen C, Lin LL, Mantchev GT, Bram RJ, Noelle RJ. BCMA is essential for the survival of long-lived bone marrow plasma cells. J Exp Med, 2004, 199: 91-98

130 Ramanujam M, Wang X, Huang W, Schiffer L, Grimaldi C, Akkerman A, Diamond B, Madaio MP, Davidson A. Mechanism of action of transmembrane activator and calcium modulator ligand interactor-Ig in murine systemic lupus erythematosus. J Immunol, 2004, 173: 3524-3534

131 Day ES, Cachero TG, Qian F, Sun Y, Wen D, Pelletier M, Hsu YM, Whitty A. Selectivity of BAFF/BLyS and APRIL for binding to the TNF family receptors BAFFR/BR3 and BCMA. Biochemistry, 2005, 44: 1919-1931

132 Tangye SG, Bryant VL, Cuss AK, Good KL. BAFF, APRIL and 
human B cell disorders. Semin Immunol, 2006, 18: 305-317

133 Ota M, Duong BH, Torkamani A, Doyle CM, Gavin AL, Ota T, Nemazee D. Regulation of the B cell receptor repertoire and self-reactivity by BAFF. J Immunol, 2010, 185: 4128-4136

134 Liu Z, Davidson A. BAFF and selection of autoreactive B cells. Trends Immunol, 2011, 32: 388-394

135 Mackay F, Woodcock SA, Lawton P, Ambrose C, Baetscher M, Schneider P, Tschopp J, Browning JL. Mice transgenic for BAFF develop lymphocytic disorders along with autoimmune manifestations. J Exp Med, 1999, 190: 1697-1710

136 Stohl W, Jacob N, Guo S, Morel L. Constitutive overexpression of BAFF in autoimmune-resistant mice drives only some aspects of systemic lupus erythematosus-like autoimmunity. Arthritis Rheum, 2010, 62: 2432-2442

137 Gross JA, Johnston J, Mudri S, Enselman R, Dillon SR, Madden K, Xu W, Parrish-Novak J, Foster D, Lofton-Day C, Moore M, Littau A, Grossman A, Haugen H, Foley K, Blumberg H, Harrison K, Kindsvogel W, Clegg CH. TACI and BCMA are receptors for a TNF homologue implicated in B-cell autoimmune disease. Nature, 2000, 404: 995-999

138 Gross JA, Johnston J, Mudri S, Enselman R, Dillon SR, Madden K, Xu W, Parrish-Novak J, Foster D, Lofton-Day C, Moore M, Littau A, Grossman A, Haugen H, Foley K, Blumberg H, Harrison K, Kindsvogel W, Clegg CH. Expressions of BAFF/BAFF receptors and their correlation with disease activity in Chinese SLE patients. Lupus, 2010, 19: 1534-1549

139 Petri M, Stohl W, Chatham W, McCune WJ, Chevrier M, Ryel J, Recta V, Zhong J, Freimuth W. Association of plasma B lymphocyte stimulator levels and disease activity in systemic lupus erythematosus. Arthritis Rheum, 2008, 58: 2453-2459

140 Eilertsen GO, Van Ghelue M, Strand H, Nossent JC. Increased levels of BAFF in patients with systemic lupus erythematosus are associated with acute-phase reactants, independent of BAFF genetics: a case-control study. Rheumatology (Oxford), 2011, 50: 2197-2205

141 McCarthy EM, Lee RZ, Ní Gabhann J, Smith S, Cunnane G, Doran MF, Howard D, O'Connell P, Kearns G, Jefferies CA. Elevated B lymphocyte stimulator levels are associated with increased damage in an Irish systemic lupus erythematosus cohort. Rheumatology (Oxford), 2013, 52: 1279-1284

142 Koyama T, Tsukamoto H, Miyagi Y, Himeji D, Otsuka J, Miyagawa H, Harada M, Horiuchi T. Raised serum APRIL levels in patients with systemic lupus erythematosus. Ann Rheum Dis, 2005, 64: 1065-1067

143 Stohl W, Metyas S, Tan SM, Cheema GS, Oamar B, Roschke V, Wu Y, Baker KP, Hilbert DM. Inverse association between circulating APRIL levels and serological and clinical disease activity in patients with systemic lupus erythematosus. Ann Rheum Dis, 2004, 63: 1096-1103

144 Thien M, Phan TG, Gardam S, Amesbury M, Basten A, Mackay F, Brink R. Excess BAFF rescues self-reactive B cells from peripheral deletion and allows them to enter forbidden follicular and marginal zone niches. Immunity, 2004, 20: 785-798

145 Ettinger R, Sims GP, Fairhurst AM, Robbins R, da Silva YS, Spolski $\mathrm{R}$, Leonard WJ, Lipsky PE. IL-21 induces differentiation of human naive and memory $\mathrm{B}$ cells into antibody-secreting plasma cells. J Immunol, 2005, 175: 7867-7879

146 Zhang X, Ing S, Fraser A, Chen M, Khan O, Zakem J, Davis W, Quinet R. Follicular helper T cells: new insights into mechanisms of autoimmune diseases. Ochsner J, 2013, 13: 131-139

147 Shulman Z, Gitlin AD, Weinstein JS, Lainez B, Esplugues E, Flavell RA, Craft JE, Nussenzweig MC. Dynamic signaling by $T$ follicular helper cells during germinal center B cell selection. Science, 2014, 345: 1058-1062

148 Vinuesa CG, Cook MC, Angelucci C, Athanasopoulos V, Rui L, Hill KM, Yu D, Domaschenz H, Whittle B, Lambe T, Roberts IS, Copley RR, Bell JI, Cornall RJ, Goodnow CC. A RING-type ubiquitin ligase family member required to repress follicular helper $\mathrm{T}$ cells and autoimmunity. Nature, 2005, 435: 452-458

149 Bubier JA, Sproule TJ, Foreman O, Spolski R, Shaffer DJ, Morse HC 3rd, Leonard WJ, Roopenian DC. A critical role for IL-21 receptor signaling in the pathogenesis of systemic lupus erythematosus in BXSB-Yaa mice. Proc Natl Acad Sci USA, 2009, 106: 1518-1523

150 Herber D, Brown TP, Liang S, Young DA, Collins M, Dunussi-Joannopoulos K. IL-21 has a pathogenic role in a lupus-prone mouse model and its blockade with IL-21R.Fc reduces disease progression. J Immunol, 2007, 178: 3822-3830

151 Nakou M, Papadimitraki ED, Fanouriakis A, Bertsias GK, Choulaki C, Goulidaki N, Sidiropoulos P, Boumpas DT. Interleukin-21 is increased in active systemic lupus erythematosus patients and contributes to the generation of plasma B cells. Clin Exp Rheumatol, 2013, 31: 172-179

152 Terrier B, Costedoat-Chalumeau N, Garrido M, Geri G, Rosenzwajg M, Musset L, Klatzmann D, Saadoun D, Cacoub P. Interleukin 21 correlates with $\mathrm{T}$ cell and B cell subset alterations in systemic lupus erythematosus. J Rheumatol, 2012, 39: 1819-1828

153 Bekeredjian-Ding IB, Wagner M, Hornung V, Giese T, Schnurr M, Endres S, Hartmann G. Plasmacytoid dendritic cells control TLR7 sensitivity of naive B cells via type I IFN. J Immunol, 2005, 174: 4043-4050

154 Uccellini MB, Busconi L, Green NM, Busto P, Christensen SR, Shlomchik MJ, Marshak-Rothstein A, Viglianti GA. Autoreactive B cells discriminate CpG-rich and CpG-poor DNA and this response is modulated by IFN-alpha. J Immunol, 2008, 181: 5875-5884

155 Braun D, Caramalho I, Demengeot J. IFN-alpha/beta enhances BCR-dependent B cell responses. Int Immunol, 2002, 14: 411-419

156 Harigai M, Kawamoto M, Hara M, Kubota T, Kamatani N, Miyasaka $\mathrm{N}$. Excessive production of IFN-gamma in patients with systemic lupus erythematosus and its contribution to induction of $\mathrm{B}$ lymphocyte stimulator/B cell-activating factor/TNF ligand superfamily-13B. J Immunol, 2008, 181: 2211-2219

157 Abdel Galil SM, Ezzeldin N, El-Boshy ME. The role of serum IL-17 and IL- 6 as biomarkers of disease activity and predictors of remission in patients with lupus nephritis. Cytokine, 2015, 76: 280-287

158 Pateinakis P, Pyrpasopoulou A. Targeting the B-cell pathway in lupus nephritis: current evidence and future perspectives. Sci World J, 2013, 2013: 745239

159 Shlomchik MJ, Madaio MP, Ni D, Trounstein M, Huszar D. The role of B cells in 1pr/lpr-induced autoimmunity. J Exp Med, 1994, 180: 1295-1306

160 Jacob N, Guo S, Mathian A, Koss MN, Gindea S, Putterman C, Jacob $\mathrm{CO}$, Stohl W. B Cell and BAFF dependence of IFN-alphaexaggerated disease in systemic lupus erythematosus-prone NZM 2328 mice. J Immunol, 2011, 186: 4984-4993

161 Rovin BH1, Furie R, Latinis K, Looney RJ, Fervenza FC, Sanchez-Guerrero J, Maciuca R, Zhang D, Garg JP, Brunetta P, Appel G, LUNAR Investigator Group. Efficacy and safety of rituximab in patients with active proliferative lupus nephritis: the Lupus Nephritis Assessment with Rituximab study. Arthritis Rheum, 2012, 64: 1215-1226

162 Merrill JT, Neuwelt CM, Wallace DJ, Shanahan JC, Latinis KM, Oates JC, Utset TO, Gordon C, Isenberg DA, Hsieh HJ, Zhang D, Brunetta PG. Efficacy and safety of rituximab in moderately-to-severely active systemic lupus erythematosus: the randomized, double-blind, phase II/III systemic lupus erythematosus evaluation of rituximab trial. Arthritis Rheum, 2010, 62: 222-233

163 Condon MB, Ashby D, Pepper RJ, Cook HT, Levy JB, Griffith M, Cairns TD, Lightstone L. Prospective observational single-centre cohort study to evaluate the effectiveness of treating lupus nephritis with rituximab and mycophenolate mofetil but no oral steroids. Ann Rheum Dis, 2013, 72: 1280-1286

164 Ezeonyeji AN, Isenberg DA. Early treatment with rituximab in newly diagnosed systemic lupus erythematosus patients: a steroid-sparing regimen. Rheumatology (Oxford), 2012, 51: 476-481

165 Pepper R, Griffith M, Kirwan C, Levy J, Taube D, Pusey C, Lightstone L, Cairns T. Rituximab is an effective treatment for lupus nephritis and allows a reduction in maintenance steroids. Nephrol Dial Transplant, 2009, 24: 3717-3723

166 Hahn BH, McMahon MA, Wilkinson A, Wallace WD, Daikh DI, 
Fitzgerald JD, Karpouzas GA, Merrill JT, Wallace DJ, Yazdany J, Ramsey-Goldman R, Singh K, Khalighi M, Choi SI, Gogia M, Kafaja S, Kamgar M, Lau C, Martin WJ, Parikh S, Peng J, Rastogi A, Chen W, Grossman JM; American College of Rheumatology. American College of Rheumatology guidelines for screening, treatment, and management of lupus nephritis. Arthritis Care Res (Hoboken), 2012, 64: 797-808

167 Favas C, Isenberg DA. B-cell-depletion therapy in SLE-what are the current prospects for its acceptance? Nat Rev Rheumatol, 2009, 5: 711-716

168 Mysler EF, Spindler AJ, Guzman R, Bijl M, Jayne D, Furie RA, Houssiau FA, Drappa J, Close D, Maciuca R, Rao K, Shahdad S, Brunetta P. Efficacy and safety of ocrelizumab in active proliferative lupus nephritis: results from a randomized, double-blind, phase III study. Arthritis Rheum, 2013, 65: 2368-2379

169 Dorner T, Kaufmann J, Wegener WA, Teoh N, Goldenberg DM, Burmester GR. Initial clinical trial of epratuzumab (humanized anti-CD22 antibody) for immunotherapy of systemic lupus erythematosus. Arthritis Res Ther, 2006, 8: R74

170 Tsuru T, Tanaka Y, Kishimoto M, Saito K, Yoshizawa S, Takasaki Y, Miyamura T, Niiro H, Morimoto S, Yamamoto J, Lledo-Garcia R, Shao J, Tatematsu S, Togo O, Koike T. Safety, Pharmacokinetics and pharmacodynamics of epratuzumab in japanese patients with moderate-to-Severe Systemic Lupus Erythematosus: results from a phase 1/2 randomized study. Mod Rheumatol, 2015: 1-19

171 Strand V, Petri M, Kalunian K, Gordon C, Wallace DJ, Hobbs K, Kelley L, Kilgallen B, Wegener WA, Goldenberg DM. Epratuzumab for patients with moderate to severe flaring SLE: health-related quality of life outcomes and corticosteroid use in the randomized controlled ALLEVIATE trials and extension study SL0006. Rheumatology (Oxford), 2014, 53: 502-511

172 Wallace DJ, Gordon C, Strand V, Hobbs K, Petri M, Kalunian K, Houssiau F, Tak PP, Isenberg DA, Kelley L, Kilgallen B, Barry AN, Wegener WA, Goldenberg DM. Efficacy and safety of epratuzumab in patients with moderate/severe flaring systemic lupus erythematosus: results from two randomized, double-blind, placebocontrolled, multicentre studies (ALLEVIATE) and follow-up. Rheumatology (Oxford), 2013, 52: 1313-1322

173 Wallace DJ, Kalunian K, Petri MA, Strand V, Houssiau FA, Pike M, Kilgallen B, Bongardt S, Barry A, Kelley L, Gordon C. Efficacy and safety of epratuzumab in patients with moderate/severe active systemic lupus erythematosus: results from EMBLEM, a phase IIb, randomised, double-blind, placebo-controlled, multicentre study. Ann Rheum Dis, 2014, 73: 183-190

174 Horton HM, Chu SY, Ortiz EC, Pong E, Cemerski S, Leung IW, Jacob N, Zalevsky J, Desjarlais JR, Stohl W, Szymkowski DE. Antibody-mediated coengagement of FcgammaRIIb and B cell receptor complex suppresses humoral immunity in systemic lupus erythematosus. J Immunol, 2011, 186: 4223-4233

175 Smolen JS, Weinblatt ME, Sheng S, Zhuang Y, Hsu B. Sirukumab, a human anti-interleukin-6 monoclonal antibody: a randomised, 2-part (proof-of-concept and dose-finding), phase II study in patients with active rheumatoid arthritis despite methotrexate therapy. Ann Rheum Dis, 2014, 73: 1616-1625

176 Greenwald M, Szczepanski L, Kennedy A, Veenhuizen M, Komocsar WJ, Polasek E, Guerrettaz K, Berclaz PY, Lee C. A 52-week, open-label study evaluating the safety and efficacy of tabalumab, an anti-B-cell-activating factor monoclonal antibody, for rheumatoid arthritis. Arthritis Res Ther, 2014, 16: 415

177 Genovese MC, Fleischmann R, Furst D, Janssen N, Carter J, Dasgupta B, Bryson J, Duncan B, Zhu W, Pitzalis C, Durez P, Kretsos K. Efficacy and safety of olokizumab in patients with rheumatoid arthritis with an inadequate response to TNF inhibitor therapy: outcomes of a randomised Phase IIb study. Ann Rheum Dis, 2014, 73: 1607-1615

178 Szepietowski JC, Nilganuwong S, Wozniacka A, Kuhn A, Nyberg F, van Vollenhoven RF, Bengtsson AA, Reich A, de Vries DE, van Hartingsveldt B, Robinson DW Jr, Gordon R, Hsu B. Phase I, randomized, double-blind, placebo-controlled, multiple intravenous, dose-ascending study of sirukumab in cutaneous or systemic lupus erythematosus. Arthritis Rheum, 2013, 65: 2661-2671

179 Illei GG, Shirota Y, Yarboro CH, Daruwalla J, Tackey E, Takada K, Fleisher T, Balow JE, Lipsky PE. Tocilizumab in systemic lupus erythematosus: data on safety, preliminary efficacy, and impact on circulating plasma cells from an open-label phase I dosage-escalation study. Arthritis Rheum, 2010, 62: 542-552

180 Group AT. Treatment of lupus nephritis with abatacept: the Abatacept and Cyclophosphamide Combination Efficacy and Safety Study. Arthritis Rheumatol, 2014, 66: 3096-3104

181 Furie R, Nicholls K, Cheng TT, Houssiau F, Burgos-Vargas R, Chen SL, Hillson JL, Meadows-Shropshire S, Kinaszczuk M, Merrill JT. Efficacy and safety of abatacept in lupus nephritis: a twelve-month, randomized, double-blind study. Arthritis Rheumatol, 2014, 66: 379-389

182 Kalunian KC, Davis JC Jr., Merrill JT, Totoritis MC, Wofsy D, Group I-LS. Treatment of systemic lupus erythematosus by inhibition of T cell costimulation with anti-CD154: a randomized, double-blind, placebo-controlled trial. Arthritis Rheum, 2002, 46: 3251-3258

183 Boumpas DT1, Furie R, Manzi S, Illei GG, Wallace DJ, Balow JE, Vaishnaw A, BG9588 Lupus Nephritis Trial Group. A short course of BG9588 (anti-CD40 ligand antibody) improves serologic activity and decreases hematuria in patients with proliferative lupus glomerulonephritis. Arthritis Rheum, 2003, 48: 719-727

184 Navarra SV, Guzmán RM, Gallacher AE, Hall S, Levy RA, Jimenez RE, Li EK, Thomas M, Kim HY, León MG, Tanasescu C, Nasonov E, Lan JL, Pineda L, Zhong ZJ, Freimuth W, Petri MA, BLISS-52 Study Group. Efficacy and safety of belimumab in patients with active systemic lupus erythematosus: a randomised, placebocontrolled, phase 3 trial. Lancet, 2011, 377: 721-731

185 Furie R, Petri M, Zamani O, Cervera R, Wallace DJ, Tegzová D, Sanchez-Guerrero J, Schwarting A, Merrill JT, Chatham WW, Stohl W, Ginzler EM, Hough DR, Zhong ZJ, Freimuth W, van Vollenhoven RF, BLISS-76 Study Group. A phase III, randomized, placebo-controlled study of belimumab, a monoclonal antibody that inhibits B lymphocyte stimulator, in patients with systemic lupus erythematosus. Arthritis Rheum, 2011, 63: 3918-3930

186 Manzi S1, Sánchez-Guerrero J, Merrill JT, Furie R, Gladman D, Navarra SV, Ginzler EM, D'Cruz DP, Doria A, Cooper S, Zhong ZJ, Hough D, Freimuth W, Petri MA, BLISS-52 and BLISS-76 Study Groups. Effects of belimumab, a B lymphocyte stimulator-specific inhibitor, on disease activity across multiple organ domains in patients with systemic lupus erythematosus: combined results from two phase III trials. Ann Rheum Dis, 2012, 71: 1833-1838

187 Dooley MA, Houssiau F, Aranow C, D'Cruz DP, Askanase A, Roth DA, Zhong ZJ, Cooper S, Freimuth WW, Ginzler EM; BLISS-52 and -76 Study Groups. Effect of belimumab treatment on renal outcomes: results from the phase 3 belimumab clinical trials in patients with SLE. Lupus, 2013, 22: 63-72

188 Stohl W, Hiepe F, Latinis KM, Thomas M, Scheinberg MA, Clarke A, Aranow C, Wellborne FR, Abud-Mendoza C, Hough DR, Pineda L, Migone TS, Zhong ZJ, Freimuth WW, Chatham WW, BLISS-52 Study Group, BLISS-76 Study Group. Belimumab reduces autoantibodies, normalizes low complement levels, and reduces select B cell populations in patients with systemic lupus erythematosus. Arthritis Rheum, 2012, 64: 2328-2337

189 van Vollenhoven RF, Petri MA, Cervera R, Roth DA, Ji BN, Kleoudis CS, Zhong ZJ, Freimuth W. Belimumab in the treatment of systemic lupus erythematosus: high disease activity predictors of response. Ann Rheum Dis, 2012, 71: 1343-1349

190 Dall'Era M, Chakravarty E, Wallace D, Genovese M, Weisman M, Kavanaugh A, Kalunian K, Dhar P, Vincent E, Pena-Rossi C, Wofsy D. Reduced B lymphocyte and immunoglobulin levels after atacicept treatment in patients with systemic lupus erythematosus: results of a multicenter, phase Ib, double-blind, placebo-controlled, dose-escalating trial. Arthritis Rheum, 2007, 56: 4142-4150

191 Genovese MC, Kinnman N, de La Bourdonnaye G, Pena Rossi C, Tak PP. Atacicept in patients with rheumatoid arthritis and an inadequate response to tumor necrosis factor antagonist therapy: 
results of a phase II, randomized, placebo-controlled, dose-finding trial. Arthritis Rheum, 2011, 63: 1793-1803

192 van Vollenhoven RF, Kinnman N, Vincent E, Wax S, Bathon J. Atacicept in patients with rheumatoid arthritis and an inadequate response to methotrexate: results of a phase II, randomized, placebo-controlled trial. Arthritis Rheum, 2011, 63: 1782-1792

193 Ginzler EM, Wax S, Rajeswaran A, Copt S, Hillson J, Ramos E, Singer NG. Atacicept in combination with MMF and corticosteroids in lupus nephritis: results of a prematurely terminated trial. Arthritis Res Ther, 2012, 14: R33

194 Isenberg D, Gordon C, Licu D, Copt S, Rossi CP, Wofsy D. Efficacy and safety of atacicept for prevention of flares in patients with moderate-to-severe systemic lupus erythematosus (SLE): 52-week data (APRIL-SLE randomised trial). Ann Rheum Dis, 2015, 74: 2006-2015

195 Hsu H, Khare SD, Lee F, Miner K, Hu YL, Stolina M, Hawkins N, Chen Q, Ho SY, Min H, Xiong F, Boone T, Zack DJ. A novel modality of BAFF-specific inhibitor AMG623 peptibody reduces B-cell number and improves outcomes in murine models of autoimmune disease. Clin Exp Rheumatol, 2012, 30: 197-201

196 Hsu H, Khare SD, Lee F, Miner K, Hu YL, Stolina M, Hawkins N, Chen Q, Ho SY, Min H, Xiong F, Boone T, Zack DJ. A phase 2, randomised, placebo-controlled clinical trial of blisibimod, an inhibitor of B cell activating factor, in patients with moderate-tosevere systemic lupus erythematosus, the PEARL-SC study. Ann Rheum Dis, 2014, 74: 1667-1675

197 Manetta J, Bina H, Ryan P, Fox N, Witcher DR, Kikly K. Generation and characterization of tabalumab, a human monoclonal antibody that neutralizes both soluble and membrane-bound B-cell activating factor. J Inflamm Res, 2014, 7: 121-131

198 Genovese MC, Lee E, Satterwhite J, Veenhuizen M, Disch D, Berclaz PY, Myers S, Sides G, Benichou O. A phase 2 dose-ranging study of subcutaneous tabalumab for the treatment of patients with active rheumatoid arthritis and an inadequate response to methotrexate. Ann Rheum Dis, 2013, 72: 1453-1460

199 Genovese MC, Bojin S, Biagini IM, Mociran E, Cristei D, Mirea G, Georgescu L, Sloan-Lancaster J. Tabalumab in rheumatoid arthritis patients with an inadequate response to methotrexate and naive to biologic therapy: a phase II, randomized, placebo-controlled trial. Arthritis Rheum, 2013, 65: 880-889

200 Genovese MC, Fleischmann RM, Greenwald M, Satterwhite J, Veenhuizen M, Xie L, Berclaz PY, Myers S, Benichou O. Tabalumab, an anti-BAFF monoclonal antibody, in patients with active rheumatoid arthritis with an inadequate response to TNF inhibitors. Ann Rheum Dis, 2013, 72: 1461-1468

201 Genovese MC, Silverman GJ, Emery P, Gupta RC, Gill A, Veenhuizen M, Xie L, Komocsar WJ, Berclaz PY, Lee C. Efficacy and safety of tabalumab, an anti-B-cell-activating factor monoclonal antibody, in a heterogeneous rheumatoid arthritis population: results from a randomized, placebo-controlled, phase 3 trial (FLEX-O). J
Clin Rheumatol, 2015, 21: 231-238

202 Smolen JS, Weinblatt ME, van der Heijde D, Rigby WF, van Vollenhoven R, Bingham CO 3rd, Veenhuizen M, Gill A, Zhao F, Komocsar WJ, Berclaz PY, Ortmann R, Lee C. Efficacy and safety of tabalumab, an anti-B-cell-activating factor monoclonal antibody, in patients with rheumatoid arthritis who had an inadequate response to methotrexate therapy: results from a phase III multicentre, randomised, double-blind study. Ann Rheum Dis, 2015, 74: $1567-1570$

203 Isenberg DA, Petri M, Kalunian K, Tanaka Y, Urowitz MB, Hoffman RW, Morgan-Cox M, Iikuni N, Silk M, Wallace DJ. Efficacy and safety of subcutaneous tabalumab in patients with systemic lupus erythematosus: results from ILLUMINATE-1, a 52-week, phase III, multicentre, randomised, double-blind, placebo-controlled study. Ann Rheum Dis, 2015, doi: 10.1136/annrheumdis-2015-207653

204 Merrill JT, van Vollenhoven RF, Buyon JP, Furie RA, Stohl W, Morgan-Cox M, Dickson C, Anderson PW, Lee C, Berclaz PY, Dörner T. Efficacy and safety of subcutaneous tabalumab, a monoclonal antibody to B-cell activating factor, in patients with systemic lupus erythematosus: results from ILLUMINATE-2, a 52-week, phase III, multicentre, randomised, double-blind, placebocontrolled study. Ann Rheum Dis, 2015, doi: 10.1136/ annrheumdis-2015-207654

205 Neubert K, Meister S, Moser K, Weisel F, Maseda D, Amann K, Wiethe C, Winkler TH, Kalden JR, Manz RA, Voll RE. The proteasome inhibitor bortezomib depletes plasma cells and protects mice with lupus-like disease from nephritis. Nat Med, 2008, 14: $748-755$

206 Hainz N, Thomas S, Neubert K, Meister S, Benz K, Rauh M, Daniel C, Wiesener M, Voll RE, Amann K. The proteasome inhibitor bortezomib prevents lupus nephritis in the NZB/W F1 mouse model by preservation of glomerular and tubulointerstitial architecture. Nephron Exp Nephrol, 2012, 120: e47-e58

207 Hirai M, Kadowaki N, Kitawaki T, Fujita H, Takaori-Kondo A, Fukui R, Miyake K, Maeda T, Kamihira S, Miyachi Y, Uchiyama T. Bortezomib suppresses function and survival of plasmacytoid dendritic cells by targeting intracellular trafficking of Toll-like receptors and endoplasmic reticulum homeostasis. Blood, 2011, 117: 500-509

208 Ichikawa HT, Conley T, Muchamuel T, Jiang J, Lee S, Owen T, Barnard J, Nevarez S, Goldman BI, Kirk CJ, Looney RJ, Anolik JH. Beneficial effect of novel proteasome inhibitors in murine lupus via dual inhibition of type I interferon and autoantibody-secreting cells. Arthritis Rheum, 2012, 64: 493-503

209 Alexander T, Sarfert R, Klotsche J, Kuhl AA, Rubbert-Roth A, Lorenz HM, Rech J, Hoyer BF, Cheng Q, Waka A, Taddeo A, Wiesener M, Schett G, Burmester GR, Radbruch A, Hiepe F, Voll RE. The proteasome inhibitior bortezomib depletes plasma cells and ameliorates clinical manifestations of refractory systemic lupus erythematosus. Ann Rheum Dis, 2015, 74: 1474-1478

Open Access This article is distributed under the terms of the Creative Commons Attribution License which permits any use, distribution, and reproduction in any medium, provided the original author(s) and source are credited. 